\title{
Magic for the dead? The archaeology of magic in later medieval burials
}

Article

Published Version

Gilchrist, R. (2008) Magic for the dead? The archaeology of magic in later medieval burials. Medieval Archaeology, 52. pp. 119-159. ISSN 0076-6097 doi:

https://doi.org/10.1179/174581708×335468 Available at https://centaur.reading.ac.uk/3556/

It is advisable to refer to the publisher's version if you intend to cite from the work. See Guidance on citing.

To link to this article DOI: http://dx.doi.org/10.1179/174581708x335468

Publisher: Maney Publishing

All outputs in CentAUR are protected by Intellectual Property Rights law, including copyright law. Copyright and IPR is retained by the creators or other copyright holders. Terms and conditions for use of this material are defined in the End User Agreement.

\section{www.reading.ac.uk/centaur}

\section{CentAUR}

Central Archive at the University of Reading

Reading's research outputs online 
WINNER OF THE 2008 MARTYN JOPE AWARD

\title{
Magic for the Dead? The Archaeology of Magic in Later Medieval Burials
}

\author{
By ROBERTA GILCHRIST ${ }^{1}$
}

THIS PAPER EXAMINES patterns in the placement of apotropaic objects and materials in high- to late-medieval burials in Britain (I I th to I 5 th centuries). It develops an interdisciplinary classification to identify: (I) healing charms and protective amulets; (2) objects perceived to have occult natural power; (3) 'antique' items that were treated as possessing occult power; and (4) rare practices that may have been associated with the demonic magic of divination or sorcery. Making comparisons with amulets deposited in conversion-period graves

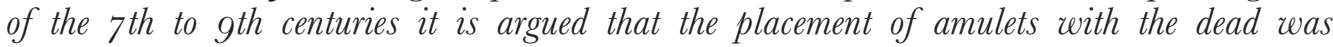
strategic to Christian belief, intended to transform or protect the corpse. The conclusion is that material traces of magic in later medieval graves have a connection to folk magic, performed by women in the care of their families, and drawing on knowledge of earlier traditions. This popular magic was integrated with Christian concerns and tolerated by local clergy, and was perhaps meant to heal or reconstitute the corpse, to ensure its reanimation on judgement day, and to protect the vulnerable dead on their journey through purgatory.

Archaeologists have been reluctant to consider how medieval people expressed supernatural and spiritual beliefs through the material practices of life and death. A rare contribution on this theme was Ralph Merrifield's The Archaeology of Ritual and Magic, in which he diagnosed a 'ritual phobia' among historical archaeologists. ${ }^{2}$ With the advent of a more scientific, processual archaeology in the I970s and I98os, the study of magic — with its superstitious and folkloric connotations - was relegated to the archaeological fringe. ${ }^{3}$ The topic has retained some currency in the study of conversion-period burials of the 7 th to 9 th centuries, although even in this context magic has been dismissed as superstitious ritual, rather than examined in relation to sacred beliefs. ${ }^{4}$

\footnotetext{
${ }^{1}$ Department of Archaeology, University of Reading, Whiteknights PO Box 227, Reading RG6 6AB, England, UK.r.l.gilchrist@reading.ac.uk

2 Merrifield i 987,5 .

${ }^{3}$ For discussion of the impact of processualism on medieval archaeology, see Gerrard 2003, I72-8. In contrast, magic has enjoyed a central position in the study of African-American historical archaeology, with its greater intellectual alliance with modern anthropology (eg Wilkie I997; Leone r 999).

${ }^{4}$ Meaney I98 I, 253; Dickinson I 993, 45. An exception is the discussion of Viking magic and religion by Price 2002.
} 
Archaeological perceptions of magic are a legacy of early anthropology: magic was regarded as 'primitive' or 'exotic', engaged in by individuals who sought practical solutions, in contrast with the more mystical and collective nature of organised religion. ${ }^{5}$ It may be that archaeologists studying the Middle Ages have found the juxtaposition of magic and Christianity particularly difficult to interrogate, based on the false assumption that these are mutually exclusive categories comprising marginal superstition on the one hand versus formalised religion on the other.

This article reviews the range of apotropaic items and materials that were included in the graves of some members of later medieval communities in Britain. The significance of these practices is traced to earlier burial traditions, in particular the increased use of amulets during the period of conversion to Christianity, and more ancient traditions of placing selected natural materials or antique objects within graves. I will review archaeological evidence according to possible connections with attested categories of later medieval magic, with the aim of recognising the intentions behind 'magic' directed towards the corpse. Was this magic healing or protective? Did it aim to safeguard the living or conjure the dead? Who were the recipients of such magical rites - and who was responsible for performing them?

\section{MAGIC, RELIGION AND THE MEDIEVAL DEAD}

Historical study of medieval magic has undergone a vibrant renaissance in the past 20 years. Theoretical discussion has focused on definitions of magic, how and why the term acquired pejorative connotations, and how distinctions emerged between medieval popular and learned forms. ${ }^{6}$ Two issues are of particular significance here: what was the relationship between early and later medieval practices of magic, and how did medieval people distinguish between religious and magical phenomena?

In the conversion of northern Europe to Christianity, the church tolerated and absorbed magical practices such as the use of healing charms, while the Christian cult of relics extolled the miraculous healing properties of the bones of saints, or any substances that had come into contact with them. Some argue that such practices were not merely 'pagan survivals', but vitally important elements that were deliberately absorbed into a new mix. ${ }^{7}$ This was not the simple fusion or syncretism of two sets of beliefs, but was instead a dynamic process that involved the sustained engagement of folk traditions and Christian practice with the Classical, Judaic and Islamic inheritance. Perhaps the most appropriate

\footnotetext{
${ }^{5}$ In The Golden Bough (I890), J G Frazer characterised magic as 'a ruder and earlier phase of the human mind, through which all the races of mankind have passed or are passing on their way to religion'. In A General Theory of Magic ( I 902), Marcel Mauss firmly established the dichotomy between magic and religion: 'A magical rite is any rite which does not play a part in organised cults - it is private, secret, mysterious and approaches the limit of a prohibited rite' (Frazer i 990, 56; Mauss I 972, 24). For general discussion of the intellectual traditions represented in the study of magic, see Cunningham I 999.

${ }^{6}$ Fanger i 998, vii; Kieckhefer I 994b, 8 I 5 .

${ }^{7}$ Flint I 99 I, 24; Kieckhefer I 994b, 825.
} 
model for understanding this rich collision of beliefs is that provided by postcolonial and diaspora theory. Just as the movement of peoples provoked social processes of 'hybridity' and 'creolisation', the conversion to Christianity juxtaposed diverse traditions; these in turn forged medieval Christianity as a hybrid cultural form. The theory of hybridity stresses agency, and this is a central concept for understanding medieval magic. ${ }^{8}$

We may detect the intersection of these beliefs in the 'final phase' or conversion-period burial practices of the 7 th and 8th centuries, pre-dating the shift to churchyard burial. Inhumation rites had entirely replaced cremation, and furnished burials had declined in number, although a minority of graves contained considerable numbers of grave goods. It has been unfashionable in recent decades to connect these changes with transformations in religious belief; scholars more usually attribute them to political or social factors, such as the emergence of dynastic kingdoms and systems of taxation. ${ }^{9}$ Innovations in the types of grave goods selected for deposition, however, could signal new ideas about the afterlife, or attitudes towards the corpse. In particular, the range of amulets placed in women's graves increased to include fossils, animal teeth, Roman coins, and waist-bags and boxes, and a new range of female jewellery featured gold and garnet necklaces with Christian symbolism, and brooches with crosses. These new forms of jewellery were Classically inspired, suggesting that the Anglo-Saxon élite were drawing on earlier Romano-British or contemporary Byzantine practices. The incidence of amulets in late-Viking graves in Scandinavia increased in the second half of the Ioth century, with the introduction to Christianity, and their use was associated particularly with women. ${ }^{10}$ John Blair has emphasised the significance of the occurrence of amulets in conversionperiod female graves in both Britain and Scandinavia, arguing that women were associated with the mortuary display of religious affiliation. ${ }^{11}$

Recent interpretations of furnished burials of the early Anglo-Saxon period have discussed graves as 'tableaux' that were intended to be viewed, forms of display or theatrical performance through which the living expressed social memory of the dead. Grave goods may have been emotive deposits rather than simple reflections of identity or status in life. ${ }^{12}$ There is no evidence that the church actively opposed the use of grave goods, and it is possible that early Christian burials were among the furnished graves of the conversion period. How would exposure or conversion to Christian beliefs about the afterlife influence the selection of grave goods? Of primary importance would be the concept of corporeal resurrection, and the need to retain the physical integrity of the body. Amulets are likely to have been selected as grave goods to transform or protect the corpse for resurrection, in preference to objects chosen previously for

\footnotetext{
${ }^{8}$ For discussion of hybridity, creolisation and the use of post-colonial and diaspora theory in archaeology, see Gosden 2004 and Lilley 2004.

${ }_{9}^{9}$ Crawford 2004, 92; Pluskowski and Patrick 2003, 46.

${ }^{10}$ Zeiten I 997, 2, 45 .

${ }^{11}$ Geake I 997, 99; Geake I 999, 203; Blair 2005, I 74.

12 Williams 2007.
} 
the impact of their commemorative display. The increased emphasis placed on amulets may have been strategic to Christian belief, an element of hybridity that transformed the material practices of Christianity.

Amulets in conversion-period graves possibly expressed Christian beliefs about the body, or denoted the grave of a female religious or burial specialist. ${ }^{13}$ The practice of placing amulets and other symbolic groups of objects with the dead largely ceased by the 8th century, although graves of the gth to i Ith centuries occasionally included single items such as coins or rings. ${ }^{14}$ Ecclesiastical sources of the 7 th to the IIth centuries show an attempt to regulate popular customs surrounding the dead, some of which the church regarded as sorcery. For example, Regino of Prüm's Ecclesiastical Disciplines, c 9o6, asks: 'Hast thou sung diabolical songs (carmina) over the dead? Thou shalt do penance for twenty days'. ${ }^{15}$ The Latin carmen may be translated as Anglo-Saxon charm, a ritual sung or chanted in metrical form, as a religious hymn or magical spell or incantation. Charms worked their remedy by means of words, and sometimes with the support of herbs or objects. Their performance was private; the audience limited to the sick, injured (or deceased) recipient of the charm. ${ }^{16}$ The Old English (Bald's) Leechbook and the Lacnunga, medical manuals that were compiled in the mid-Ioth and I Ith centuries respectively, record healing charms. The books of penance and the medical charms credit women both with practising healing magic in the home and with performing magic for the dead.

By the IIth century, the clergy had challenged this intimate relationship between women and the dead. With increasing emphasis placed on the belief in purgatory, prayers and masses replaced the popular charms and folk customs performed by women. Monks and priests became the new intermediaries who connected the living with the dead. ${ }^{17}$ Distinctions also emerged between 'popular' and 'élite' magic that to some extent divided practitioners according to gender. The élite tradition drew on Graeco-Roman models of magic: from the I2th century, magia comprised 'natural magic' and 'demonic magic'. The concept of natural magic derived from Classical authors such as Pliny (23 BC-AD 79), who proposed that certain animals, plants and minerals possessed special properties, some manifest and some resulting from 'occult' powers. In contrast, they considered demonic magic to work through the agency of the magician drawing on the power of a supernatural entity, either holy or demonic, and involved a complex interplay of human and supernatural wills. ${ }^{18}$ The conjuring of spirits or demons developed into an intellectual branch of magic that involved long, intricate rituals. Such 'necromancy' (corrupted to nigromancy, or black magic) was the preserve of the highly learned, often churchmen, who represented 'a clerical underworld'. We can distinguish this élite form of ceremonial magic from folk magic that involved shorter rituals, spells and charms

\footnotetext{
13 Geake 2003, 262.

${ }^{14}$ Hadley and Buckberry 2005, I 38-9.

${ }^{15}$ McNeill and Gamer i 965, 3 I 8.

${ }_{16}$ Olsan I 992, I 34.

${ }_{17}$ Geary 1994, 72-3.

${ }_{18}$ Kieckhefer I 994 b, 820.
} 
performed by people who may not have been literate; this popular form of magic is regarded as having been more closely linked with female practitioners. ${ }^{19}$

Would medieval people have perceived any difference between the extraordinary phenomena of magic versus religious miracles? The key to understanding their beliefs lies in the explanation of the causal forces that they invoked: had the intercession of saints, the intervention of demons, or the occult power of nature caused the marvel? ${ }^{20}$ The church was largely tolerant towards magic that drew on benign (non-demonic) agents. Pagan practices such as the AngloSaxon charms became thoroughly Christianised and may have been regarded as harnessing the occult powers of nature; while a form of learned 'angelic magic' mixed devotional and mystical practices to pursue holy purposes. The boundary between religion and magic could be indistinct: even demonic magic is definable as a type of religious practice that called upon spirits in order to seek their favour. ${ }^{21}$

\section{THE ARCHAEOLOGY OF MAGIC IN LATER MEDIEVAL BURIALS}

This study develops from a re-interpretation of burial practice in Britain that reviewed 8,00o graves dating from the IIth to the i6th centuries, and identified potential evidence for apotropaic rites directed toward the medieval dead. $^{22}$ Here I present archaeological evidence according to a new, interdisciplinary classification that draws on two contrasting approaches: I combine the archaeological typology of amulets developed by Audrey Meaney in her discussion of conversion-period graves with categories of magic that we know people practised in the high to late Middle Ages. ${ }^{23}$

I interpret patterns in grave goods placed with the later medieval dead according to the type of magic possibly intended, an approach that facilitates consideration of both the human agent behind the rite, and the causal force that it sought to invoke. Four categories of potential 'magical' item occurred in medieval graves:

- healing charms and protective amulets;

- objects believed to possess occult natural power;

- 'antique' items; and

- possible demonic magic involving divination or sorcery.

It is important to identify the placement of these magical objects in relation to the corpse, whether in direct proximity to the body, inside the shroud or coffin, or in the grave fill. Where this distinction can be made, it may be possible to

\footnotetext{
${ }^{19}$ Kieckhefer i 989; Fanger i 998, vii; Kieckhefer i 994a, 379.

${ }^{20}$ Kieckhefer i 994 b, 82 I-4.

${ }^{21}$ Jolly i 985 ; Fanger I 998, vii; Kieckhefer i 994 a, 372.

${ }_{22}$ Gilchrist and Sloane 2005, funded by the Arts and Humanities Research Council. The present study builds on this earlier co-authored work and presents new interpretations that are the responsibility of the author.

${ }^{23}$ Meaney i98I; Skemer 20o6; Olsan 2003; Kieckhefer i 989, i 997.
} 
identify at what point in the funerary sequence the item was placed, whether in the home during preparation of the corpse or, subsequently, within the ecclesiastical domain of the churchyard or cemetery. This attention to sequence may permit us to infer who undertook magic for the dead, and whether these were secret rites performed in private or more public rituals that engaged the wider community. ${ }^{24}$

This discussion begins with a caveat. The material traces of magic in medieval burials are rare exceptions to the norm of Christian burial in a shroud, lacking coffin, personal items or grave goods. We observe these rites in roughly $2 \%$ of excavated and published medieval burials. Paradoxically, this low incidence may help to identify these mortuary practices as meaningful: we can consider medieval magic by definition to be exceptional, and alternative to normative rites. ${ }^{25}$ Close parallel with earlier mortuary practices provides further credence, suggesting that these customs incorporated folk traditions. But other practical factors may partially account for their low incidence. Many of the material residues of magic that were placed in graves are organic, including substances such as parchment, hair, leather, beeswax, wood, and plant and animal parts. Those that survive from exceptional circumstances of preservation may represent a fraction of the original deposition. Secondly, the magic significance of some materials is not always realised during the process of excavation and recording. Seemingly natural items in grave fills, such as white stones or fossil echinoids, may be overlooked; ubiquitous objects such as spindle whorls may be regarded as accidental losses in cemeteries; and artefacts that pre-date medieval graves are frequently dismissed as residual, in some cases even where they were placed directly on the body or occur in the sealed context of a coffin. ${ }^{26}$

\section{AMUlets: HeAling GHARMS AND APOTROPAiG OBJEGTS}

An amulet is an object worn on the body or kept in the home to preserve against affliction; its protective power can be apotropaic, therapeutic or exorcistic. Many medieval amulets drew their power from the magical efficacy of words, ranging from brief inscriptions on jewellery and religious medals, to more elaborative texts written on parchment, folded and bound to the body or carried in pouches or capsules around the neck. ${ }^{27}$ We can discuss amulets recovered from graves according to three distinct medieval forms: textual amulets, charms and consecrated objects. I propose a fourth category here based on connections with earlier burial traditions.

\footnotetext{
${ }^{24}$ Gilchrist and Sloane 2005, 227.

${ }^{25}$ Jolly 2002, 3 .

${ }^{26}$ For example, the significance of 'white stones' in medieval burials at the parish church of Kellington was not realised until some time into the excavation (Richard Morris pers comm). This was also the case at Whithorn where a total of I 3,000 'white stones' was recovered from stratified deposits (Hill I 997, 472-3).

27 Skemer 2006.
} 


\section{Textual amulets}

This type of amulet peaked in use from the I $3^{\text {th }}$ to the I $5^{\text {th }}$ centuries. Commonly used to assist childbirth, a parchment or scroll based on the measure of the body of Christ, or inscribed with prayers or the names of saints, was wrapped around women in labour. ${ }^{28}$ Textual amulets were also folded and placed on open wounds to staunch blood, and special-purpose amulets could be used on any part of the body, applied to the afflicted area. ${ }^{29}$ Textual amulets are very unlikely to survive in archaeological contexts, but two female burials contain items that are candidates. A mature adult female from the eastern cemetery at the Benedictine priory of St James, Bristol (Avon), was buried with a small parcel on her abdomen, formed from a sheet of lead. The lead was carefully folded into a rectangular package that contained a granular material thought to be parchment. The second example is from the cemetery of the hospital of St Mary Spital, City of London, where archaeologists found a wrapped textile bundle containing a granular material, possibly parchment, between the legs of an adult female. ${ }^{30}$

In Roman magic, lead packages or tablets represented malevolent spells or curses, but lead was used in medieval contexts for magico-medical procedures: for example, lead squares (laminae) were used to help women conceive, or to treat anthrax fistules. ${ }^{31}$ Christian amulets from Scandinavia were inscribed on lead rolls, tablets and crosses, often folded to contain the text of a prayer or formula. ${ }^{32}$ A further seven burials at St James, Bristol, contained fragments of folded lead, some of which might have served as amulets. ${ }^{33}$ Medieval healing charms were written on parchment, lead, tin, parts of the body, or on communion wafers and other edible items, in order to be consumed. The physical act of folding is likely to have been essential to the magical rite; it kept the formula secret and was thought to preserve its power. ${ }^{34}$

\section{Healing and protective charms}

Later medieval charms were usually religious in nature and comprised mystical words (such as ANIZAPTA) or traditional Christian names, such as those of the Magi. They were more often recited or sung but were also inscribed on jewellery or other forms of material culture. We seldom recover apotropaic jewellery from graves, and celebrated examples such as the Middleham Jewel (North Yorkshire) and the Ingelby Arncliffe Crucifix (North Yorkshire) were metal-detected or chance finds. ${ }^{35}$

\footnotetext{
${ }^{28}$ Ibid, 237; Bühler r 964; Keickhefer ı 989, 78.

${ }^{29}$ Page 2004, 30; Skemer 2006, I 36.

${ }^{30}$ Jackson 2006, I 4 I; Gilchrist and Sloane 2005, 200.

31 Merrifield I 987, I 37-42; Skemer 2006, I 28.

32 MacLeod and Mees 2006, i 90.

${ }^{33}$ Jackson 2006, 73-86.

34 Olsan 2003, 362 .

${ }^{35}$ Ibid, 357; Jones and Olsan 2000; Skemer 2006, I o, I 58-9.
} 
One clear example of a charm included in a burial is that of a woman from the cemetery of St Mary Spital (Fig I). She was buried in an ash-lined coffin with a silver ring dating to the I 4 th century. This has a two-line inscription around the outside of the ring, IASPAR MELCHIOR BALTACZAR IESUS NAZARENUS, which is a charm to ward off sudden death. ${ }^{36}$ Medieval people greatly feared death without preparation, since the last rites of confession, communion and the sacrament of extreme unction were required to send the soul on its journey. Rings as objects were credited with prophylactic properties from the Roman period onwards, ${ }^{37}$ but in many cases their occurrence in medieval graves may simply indicate a clothed burial. The inscription on the Spital ring is concrete evidence of a protective charm in a medieval English grave. ${ }^{38}$

The name of Christ was considered powerful protection against demonic agents such as ghosts. It was used apotropaically in England from the end of the I 2 th century, engraved on material culture in the abbreviated trigram IHS (from the Greek IHCOYC, Jesus). ${ }^{39}$ Inscription of the Holy Name may have come to represent an amulet in priests' burials, and examples of inscribed patens appear as grave goods with priests (together with the chalice). For example, 'J. Nazarenus' was inscribed on a paten from a I 4 th-century priest's burial in the chancel at the parish church of All Saints, Barton Bendish (Norfolk). The trigram was scratched on a sandstone pillow found in a grave in the choir at the Carmelite friary in Coventry (West Midlands), dating to c I $400 .{ }^{40}$

Wooden staffs, also termed wands or rods, regularly appear as Christian grave goods and could be objects associated with the performance of a protective

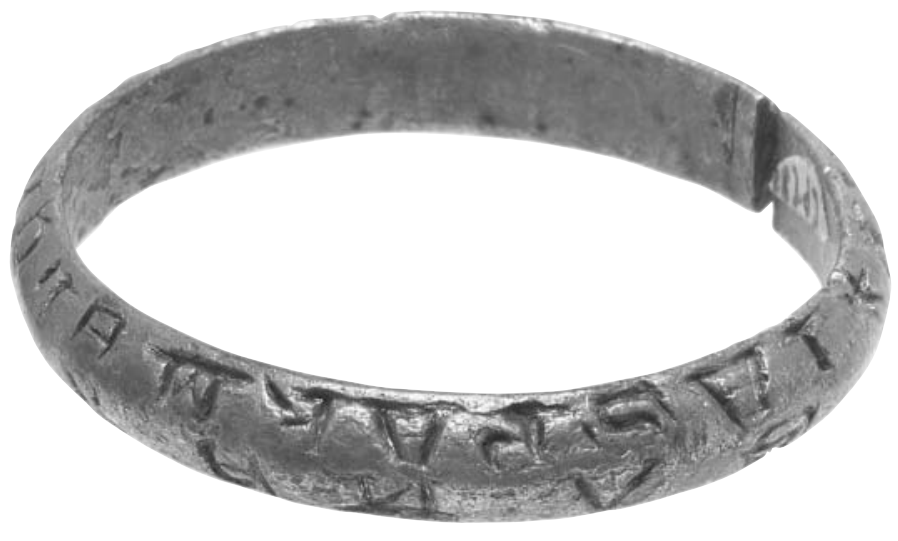

FIG I

A charm from the ash-lined coffin of a woman in the cemetery of St Mary Spital, London, dating to the I $4^{\text {th }}$ century. The two-line inscription around the outside of the finger ring, IASPAR MELCHIOR BALTACZAR IESUS NAZARENUS, is a charm to ward off sudden death. Copyright and courtesy of Museum of London Archaeology Service.

\footnotetext{
${ }^{36}$ Nailer 2003, 373; the names of the three kings were invoked also in charms against epilepsy or falling sickness (Skemer 2006, 62).

${ }^{37}$ Meaney i 98 I, I 74.

38 Amulets are known from Scandinavian burials, including a medical charm written on bronze and found in a I 2 th-century grave from Högstena, Sweden, and a liturgical text inscribed on a copper amulet from a grave in Vassunda, Sweden (MacLeod and Mees 2006, I 30, 205).

39 Skemer 2006, 70; Hinton 2005, i 9o; Blake et al 2003, I 75-203.

${ }^{40}$ Rogerson et al i 987, 28; Woodfield 2005, I 30, I 45 .
} 
charm. Mourners placed the rods either in the coffin or more often in the grave cut as part of a graveside rite that occurred in British monastic and parish cemeteries from the I Ith century up to the $\mathrm{I} 4$ th and I 5 th centuries. ${ }^{41}$ They were deposited with men, women and children, and also occurred with priests' buri-

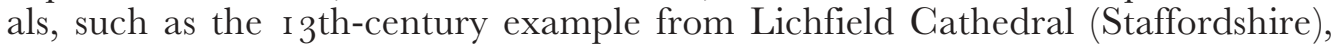
buried with a wand in the cist, a cross formed from twigs, a chalice and paten, and a eucharistic wafer. ${ }^{42}$ The rods were of coppiced hazel, ash or willow, and while single rods were most common, a priest's burial from the nave at Hulton Abbey (Staffordshire) contained six wooden staffs and a beeswax chalice (dated I 220-I350). The length of the staffs placed in medieval graves varied from short poles under I $\mathrm{m}$, to longer rods the full length of the grave.

The lack of wear and the insubstantial nature of the staffs suggest that these were items made especially for burial. ${ }^{43}$ One suggestion is that they represent a link with pilgrimage or journeying, or that the quick-growing coppices used for the poles symbolised the Resurrection and eternal life. ${ }^{44}$ The ash, hazel and willow trees are all characterised by production of whippy shoots that supplied ideal materials for the construction of medieval houses and fences. In addition to these domestic connotations, a variety of symbolic and protective powers were attributed to them. Ash (Fraxinus excelsior) healed children and protected from serpents, ${ }^{45}$ and willow infusions (containing salicylic acid) treated diseases caused by dampness. This was based on the principle of sympathetic magic, whereby things grown in damp conditions could cure illnesses exacerbated by the damp. Hazel (Corylus avellana) had a variety of purposes, from symbolising virginity to representing token rents or tally-sticks. ${ }^{46}$

I suggest that the rods may be an example of the hybridity of Christian burial customs with earlier magic. The use of wands or rods in Christian burials occurred in Scandinavia by c AD I оoo, perhaps developing from late-Iron-Age shamanistic practices. Archaeologists have recovered staffs of iron, bronze and wood from Viking burials of the gth and Ioth centuries, predominantly associated with women. Neil Price has argued that these staffs were connected to seiðr, a form of magic linked with the Old Norse gods Oðinn and Freya. He proposes that staffs were the most distinctive part of the sorcerer's equipment, used to summon spirits and to perform particular magical rites. ${ }^{47}$ Runic staffs or

\footnotetext{
${ }^{41}$ Including the parish churches of Barton-on-Humber (Humberside), St Lawrence Jewry, City of London, St Nicholas Aberdeen, and the religious houses of Glastonbury Abbey (Somerset), Hull Augustinian Friary, Hulton Abbey, Sandwell Priory, Bordesley Abbey (Hereford and Worcester), St Mary Spital, Chester Abbey, St Albans Abbey, Lichfield Cathedral and St Giles' Cathedral, Edinburgh (Gilchrist and Sloane 2005, I 26, I 7 I -4$)$.

42 Rodwell 2006, 6.

${ }^{43}$ This rite may be distinguished from staff burials that include the accoutrements of pilgrimage, such as those from Worcester Cathedral and Hulton Abbey, where the corpse was dressed in boots and accompanied by a pilgrim souvenir, and a possible example from Lichfield Cathedral that included a decayed staff and possible leather bag (Lubin I 990; Klemperer and Boothroyd 2004, I32; Rodwell 2006, 6).

44 Daniell I 997 , i i 9.

${ }^{45}$ In I 597, John Gerard's Historie of Plants noted that the leaves of the ash tree 'applied or taken with wine cure the bitings of vipers, as Dioscorides said "The leaves of this tree are of so greate virtue against serpents as that they dare not so much as touch the morning and evening shadows of the tree, but shun them afar off as Pliny reports"' (Grieve I 93I).

${ }_{46}$ Mabey i 996, 9I, I 43 .

47 Price 2002, $175^{-204}$.
} 
'healing sticks' remained in use in Scandinavia up to the high Middle Ages, with

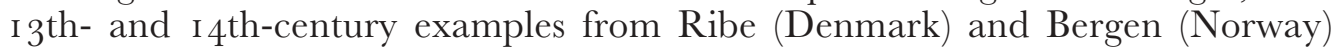
incorporating Christian invocations to the saints. ${ }^{48}$

A charm in Old English metrical verse demonstrates use of staffs in charms that would have been familiar to medieval religious communities. An I Ithcentury manuscript given to Exeter Cathedral by Leofric (d I072) records this journeying charm:

I secure myself by means of this staff, and commend myself to the protection of God, against the painful stitch, against the painful blow, against the grim horror, against the great terror which is hateful to everyone, and against all the harm that may go into the land.

I chant a victory charm: I carry a victory staff; victory by means of words, and victory by means of an object.

May they be powerful for me, so that no nightmare may come against me, nor may my stomach trouble me,

nor may fear come upon me for my life,

but may the Almighty and the Son and the Comforting Spirit save me ... ${ }^{49}$

The occurrence of staffs in later medieval priests' graves, in addition to those of laymen, women and children, suggests that there was no lingering connection between timber rods and Viking traditions of sorcery. We may interpret the rod as an object used traditionally in a journeying or healing charm, but which acquired heightened mortuary significance in the later medieval period, with adoption of the Christian metaphor of death as an arduous journey of purgation. This symbolism is most evident in Psalm 23: 'For although I walk in the midst of the shadow of death, I will fear no evil, since you are with me; your rod and your staff console me.' It is possible that the rods were carried in the procession of the corpse to the churchyard (as depicted at the death of Edward the Confessor on the Bayeux Tapestry), and then deposited at the graveside while a charm was recited. The relatively common occurrence of symbolic staffs in Christian graves suggests that these were charms to protect the dead on their journey into purgatory, made more efficacious by the use of ash or hazel woods. Theological accounts confirm a medieval perception that the dead needed protection from physical harm. Caroline Bynum has noted that Thomas Aquinas and William de la Mare discussed purgatory in 'strikingly somatic terms', with 'corporealized souls' undergoing complex journeys between death and resurrection that involved the bodily experience of suffering. ${ }^{50}$

\section{Consecrated objects}

People sometimes wore items purchased at holy shrines on the body as amulets, including commercially produced pilgrim badges and Agnus Dei discs made from the wax of consecrated candles and worn as pendants (Tab I). Direct

\footnotetext{
${ }^{48}$ MacLeod and Mees 2006, I 27, I 24, I 58.

${ }^{49}$ Cambridge Corpus Christi MS 4I, 350; Grendon i 9o9, I 76-9.

${ }^{50}$ Bynum I 995, 28I .
} 
TABLE I

PILGRIM SOUVENIRS ASSOCIATED WITH LATER MEDIEVAL BURIALS IN BRITAIN

\begin{tabular}{|c|c|c|c|c|}
\hline Site & Date & Age and sex & Comments & Source \\
\hline $\begin{array}{l}\text { Hospital of St Giles, } \\
\text { Brompton Bridge } \\
\text { (North Yorkshire) }\end{array}$ & $\begin{array}{l}\text { Mid-I } 3^{\text {th }} \\
\text { Century }\end{array}$ & Adult male & $\begin{array}{l}\text { Two lead badges } \\
\text { from Lucca and } \\
\text { Rome; placed on } \\
\text { chest }\end{array}$ & Cardwell i995 \\
\hline $\begin{array}{l}\text { Parish church of } \\
\text { St Helen-on-the- } \\
\text { Walls, York (North } \\
\text { Yorkshire) }\end{array}$ & I 2 th century & Young male & Possible lead badge & $\begin{array}{l}\text { Dawes and Magilton } \\
\text { I } 980, \text { I } 5\end{array}$ \\
\hline $\begin{array}{l}\text { St Augustine's } \\
\text { Abbey, Canterbury } \\
\text { (Kent) }\end{array}$ & After $135^{\circ}$ & $\begin{array}{l}\text { Child; 7-10 } \\
\text { years }\end{array}$ & $\begin{array}{l}\text { Six-pointed lead } \\
\text { star; burial near } \\
\text { south porch }\end{array}$ & $\begin{array}{l}\text { Sherlock and Woods } \\
\text { 1 } 988,66 \text {, fig } 69\end{array}$ \\
\hline $\begin{array}{l}\text { Parish church of St } \\
\text { Nicholas, Aberdeen } \\
\text { (Aberdeen City) }\end{array}$ & I $5^{\text {th }}$ century & $\begin{array}{l}\text { Female; } \\
\text { middle-aged }\end{array}$ & $\begin{array}{l}\text { Pièta badge; } \\
\text { pathology: rickets }\end{array}$ & $\begin{array}{l}\text { Aberdeen City } \\
\text { Council Archaeology } \\
\text { Unit 2007, I6 }\end{array}$ \\
\hline $\begin{array}{l}\text { Parish church of St } \\
\text { Nicholas, Aberdeen }\end{array}$ & 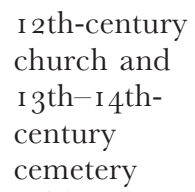 & $\begin{array}{l}\text { Not yet } \\
\text { reported }\end{array}$ & $\begin{array}{l}\text { Two burials: two } \\
\text { scallop shells next } \\
\text { to the head of one; } \\
\text { one pierced scallop } \\
\text { shell by left leg }\end{array}$ & Ibid, 8, I3 \\
\hline $\begin{array}{l}\text { Parish church of St } \\
\text { Helen Fishergate, } \\
\text { York }\end{array}$ & $\begin{array}{l}\text { Mid-I } 4 \text { th to } \\
\text { mid-I } 5^{\text {th }} \\
\text { century }\end{array}$ & $\begin{array}{l}\text { Female; } \\
\text { mature }\end{array}$ & $\begin{array}{l}\text { Scallop shell, } \\
\text { possibly in bag }\end{array}$ & $\begin{array}{l}\text { Archaeological } \\
\text { Planning } \\
\text { Consultancy }\end{array}$ \\
\hline $\begin{array}{l}\text { Worcester Cathedral } \\
\text { (Hereford and } \\
\text { Worcester) }\end{array}$ & $\begin{array}{l}\text { I } 5 \text { th or I } 6 \text { th } \\
\text { century }\end{array}$ & Male; elderly & $\begin{array}{l}\text { Scallop shell; boots } \\
\text { and staff }\end{array}$ & Lubin I990 \\
\hline
\end{tabular}

physical contact with a relic or shrine sacralised these objects, turning them into secondary relics that possessed apotropaic power. ${ }^{51}$ The pilgrim badges that are common in some urban waterfront deposits are rare in graves in Britain, and we have records of less than Ioo from burials across Europe. ${ }^{52}$ We must consider taphonomic factors, given that the metal alloy of the pewter badges (tin and lead) would oxidise rapidly outside waterlogged conditions. An interesting example is a badge depicting the Pièta from the grave of a middle-aged woman at the East Kirk of St Nicholas in Aberdeen. The woman was buried in the I $5^{\text {th }}$ century in the chapel of St Mary (possibly dedicated to Our Lady of Pity), and she suffered from severe osteomalacia (adult rickets). The Pièta iconography is

\footnotetext{
${ }^{51}$ Murray Jones 2007, I I-2; Skemer 2006, 68.

52 Andersson listed 4 I Scandinavian graves that included pilgrim badges, largely comprising scallop shells from Compostella, placed on the chest or arms of males buried in monasteries before c I 400 (Andersson ig89, I $4 \mathrm{I}^{-}$54). A further 24 examples of scallop shells are recorded from male graves in Baden-Württemburg, dated c I 200 (Haasis-Berner I999, 274).
} 
unusual and not easily linked with a contemporary pilgrim shrine. The badge may have been chosen for its resonance with the dedication of the chapel: the Pièta imagery appealed particularly to secular women, and it is likely to have served as an amulet. ${ }^{53}$

Pilgrims wore scallop shells as symbols of completion of their journey to the shrine of St James de Compostella (Spain). Burials at St Nicholas, Aberdeen, included one from the I 2th-century church with two scallop shells near the head, possibly once attached to a pilgrim's hat; and another from the later cemetery had a shell that may have been associated with a bag. A pierced scallop shell lay close to the waist of a mature female from the parish church of St Helen's Fishergate, York, possibly suspended from a belt or bag (Fig 2). The species in this case (Pecten jacobaeus) is from the Mediterranean Sea, confirming that this particular shell was a souvenir from the $\mathrm{N}$ coast of Spain. ${ }^{54}$ Medieval clothes did not have pockets, making it necessary for pilgrims to travel with their belongings in bags suspended from their belts. Waist-bags were also significant for holding the amulets that were included in conversion-period burials, and bags and pouches carried later medieval textual amulets..$^{55}$

The papal bulla, a lead seal from a papal document (Fig 3), is an example of a consecrated object placed in graves in direct physical contact with the corpse. Archaeologists have recovered approximately 6o papal bullae from medieval graves in Europe, half of which derive from English burials of the I $4^{\text {th }}$ or $5^{\text {th }}$ centuries ${ }^{56}$ Currently 20 examples are from burials at religious houses in England and Wales, and a further three from cathedrals and nine from parish churches. ${ }^{57}$ These items were contained within the shroud, placed on the chest and sometimes held in the hand of the corpse. Buried only with adults, approximately half of the known English bullae were associated with women, confirming that this rite was linked with the laity. This contrasts with the interpretation of bullae recovered from French graves, assumed to have been associated with priests, and interpreted as 'passports to redemption' that served as proof that a deceased cleric had been absolved of his $\sin .^{58}$

The bulla may have been attached to a papal indulgence that pertained to the deceased individual, or the lead seal itself may have served as an amulet. A large number of lead bullae dating from the i 2 th to the i $5^{\text {th }}$ centuries come from excavated settlements and as metal-detector finds. Their distribution suggests use also as amulets in the home and that they may have circulated

\footnotetext{
53 Aberdeen City Archaeology Unit 2007; Marks 2004, I 23.

${ }^{54}$ Archaeological Planning Consultancy.

${ }^{55}$ Geake i997, 80-8I; Skemer 2006, I 56.

${ }^{56}$ Markus Sanke pers comm; Dabrowska 2005, 334-6; Dabrowska et Comte i 993.

${ }^{57}$ You can consult a list of contexts in Gilchrist and Sloane 2005, 94-6. Four further examples have come to light: one from an adult female buried at Winchester Blackfriars with a bulla of John XII ( I 3 I 6-34) (Tim Pestell pers comm); one from the parish church of St Peter's, Leicester, with a bulla of Innocent VI, I $352-62$ (Gnanaratnam 2006a); one from the chancel of the parish church of Angmering, West Sussex, with a bulla of Boniface VIII, I 389-I 404 (Bedwin I 975, 28); and a bulla of Clement VI (I 342-52) from the grave of Bishop Trilleck, recovered from the presbytery of Hereford Cathedral in I8I 3 (Havergal I 869, I48). There are other possible examples recovered from cemetery soils but not associated with particular grave cuts, for example from Glastonbury Abbey a bulla of Calistus III, I 445-58 (Bligh Bond I 9 I 4, 4I).

${ }^{58}$ Dabrowska 2005, 334-6.
} 


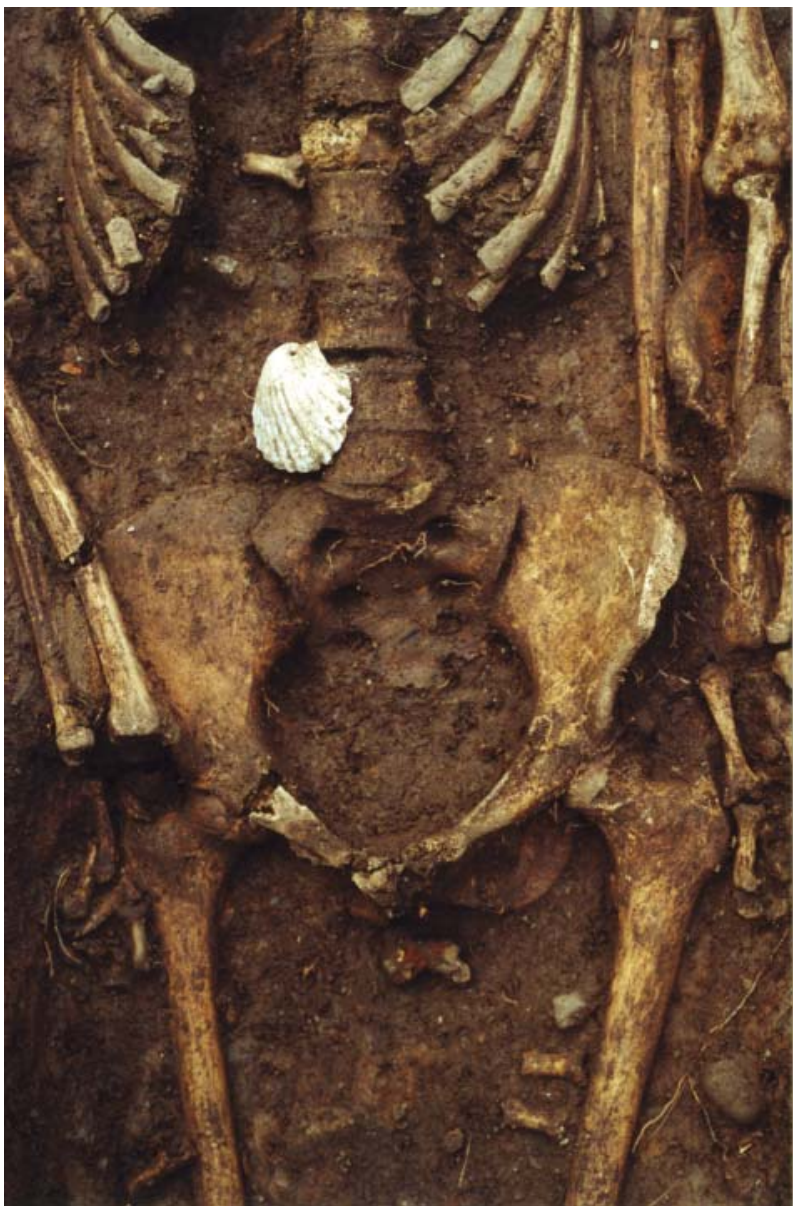

FIG 2

Female burial at St Helen's Fishergate, York, containing pierced scallop shell likely to have been suspended from a belt or bag. Copyright and courtesy of Field Archaeology Specialists.

long after they had been detached from documents. For example, a bulla from Dunkeld (Perthshire and Kinross) of Innocent IV ( I 243-54) was centrally perforated and reused as a spindle whorl. ${ }^{59}$ From burial contexts, bullae date more narrowly from the $4_{4}$ th and $5_{5}$ th centuries and may represent a rite that developed in specific response to the Black Death. It is not clear whether people prized the document or the bulla for its apotropaic powers, but we can make comparisons with the earlier tradition of the use of portrait coins, medallions and anthropomorphic bracteates for protective purposes. Images of the emperor or king's head were put to magical use in early-medieval contexts from Byzantium to Western Europe, worn on the body, incorporated into battle helmets or sacred metalwork, placed in the home or deposited in graves. ${ }^{60}$ The images 


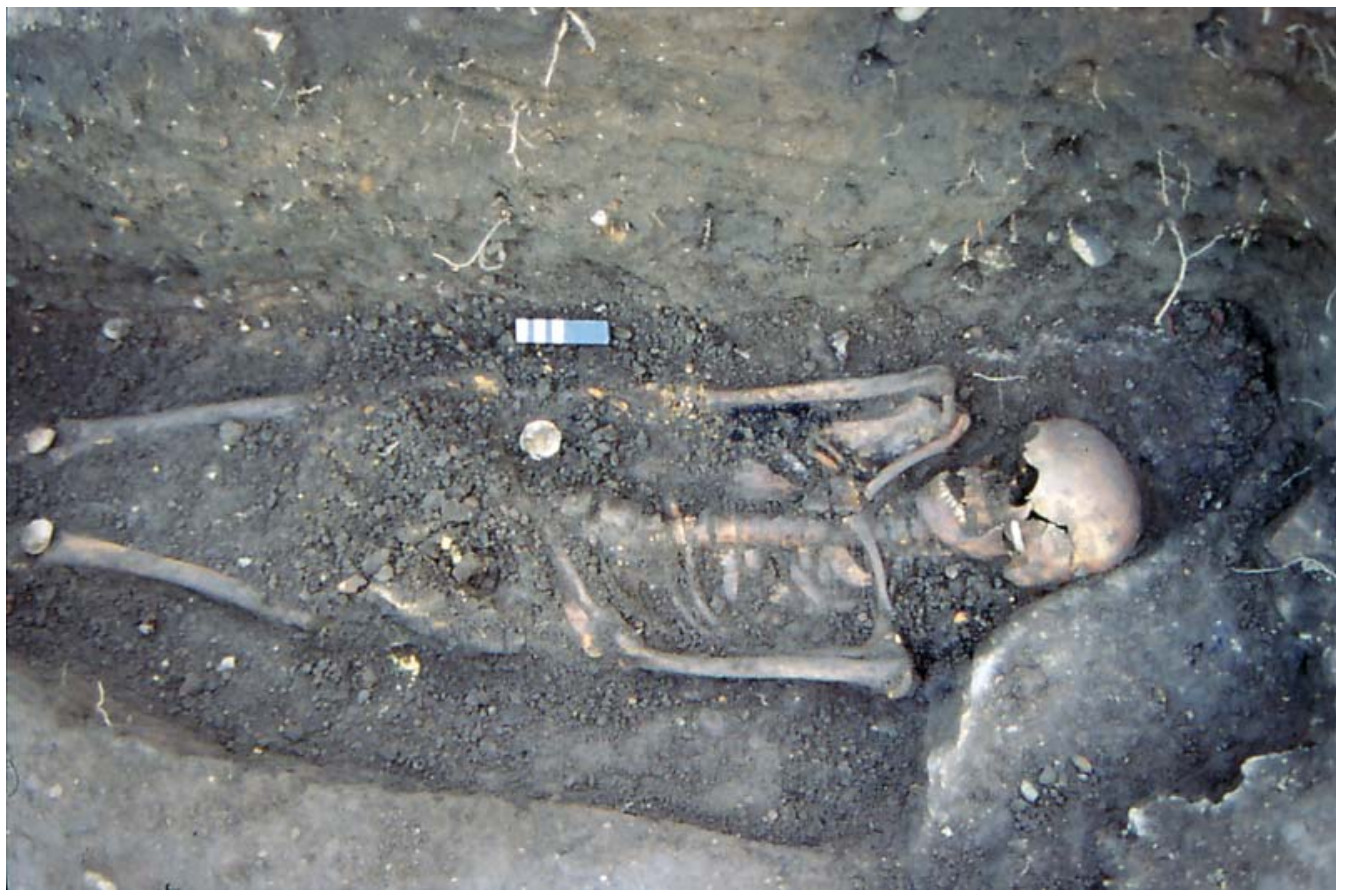

FIG 3

Ash burial in the nave of the parish church of St Peter's, Leicester, containing a bulla of Innocent VI (1352-62). Copyright and courtesy of University of Leicester Archaeological Services.

of SS Peter and Paul on bullae possibly had an apotropaic purpose similar to Roman and Byzantine ruler portraits. The name of the pope inscribed on the bulla may have served as a textual amulet, just as others used divine and sacred names for protective purposes.

\section{Traditional mortuary amulets?}

Other items occasionally deposited in medieval graves are reminiscent of the amulets placed in conversion-period female interments, including single beads, coins and spindle whorls. Single beads have been reported from graves at St Nicholas, Aberdeen, made from bone, glass, ceramic and jet; wooden beads have been recovered from burials at Ballyshannon (Co Donegal); and a single yellow glass bead (of unknown date) was placed in the interment of an adult female at Jarrow (Tyne and Wear). ${ }^{61}$

Spindle whorls were buried routinely with early-medieval women as symbols of their rôles as keepers of the house and family, and a charm from the I oth-century Leechbook notes their use for curing 'cheek disease'. ${ }^{62}$ Later medieval examples have been dismissed as residual or casual losses, but one from a sealed

${ }^{61}$ Aberdeen City Archaeology Unit 2007, I 7; Cramp 2005, 259.

${ }^{62}$ Meaney ig8I, 206. 
TABLE 2

SPINDLE WHORLS ASSOGIATED WITH LATER MEDIEVAL BURIALS IN BRITAIN

\begin{tabular}{|c|c|c|c|c|}
\hline Site & Date & Age and sex & Comments & Source \\
\hline $\begin{array}{l}\text { Whithorn } \\
\text { Cathedral Priory } \\
\text { (Dumfries and } \\
\text { Galloway) }\end{array}$ & $\begin{array}{l}\text { Period V: } \\
\text { I } 2 \text { th-I } 3^{\text {th }} \\
\text { century }\end{array}$ & Not reported & $\begin{array}{l}\text { Seven lead whorls; } \\
\text { from grave fills }\end{array}$ & Hill г997, 39 I \\
\hline $\begin{array}{l}\text { Hospital of St Mary } \\
\text { Spital, City of } \\
\text { London }\end{array}$ & $\begin{array}{l}\text { I } 4^{\text {th }- \text { I } 6 \text { th }} \\
\text { century }\end{array}$ & Male & Southern cemetery & $\begin{array}{l}\text { Gilchrist and } \\
\text { Sloane } 2005, \text { IO2 }\end{array}$ \\
\hline $\begin{array}{l}\text { Cistercian abbey } \\
\text { of Stratford } \\
\text { Langthorne } \\
\text { (Greater London) }\end{array}$ & c I $23^{0}-\mathrm{I} 35^{\circ}$ & Male & $\begin{array}{l}\text { Chalk; placed on the } \\
\text { chest, in sealed lead } \\
\text { coffin }\end{array}$ & $\begin{array}{l}\text { Barber et al } \\
2004,4 \cdot 4\end{array}$ \\
\hline $\begin{array}{l}\text { Village of Upton } \\
\text { (Gloucestershire) }\end{array}$ & I $3^{\text {th }}$ century & $\begin{array}{l}\text { Infant, } 3^{-6} \\
\text { months }\end{array}$ & $\begin{array}{l}\text { Limestone; under } \\
\text { floor of long-house }\end{array}$ & $\begin{array}{l}\text { Rahtz I969, } \\
86-8\end{array}$ \\
\hline
\end{tabular}

coffin at Stratford Langthorne must have been deliberately placed with the corpse (Tab 2). At the village of Upton, an infant aged between three to six months was buried in the $13^{\text {th }}$ century with a spindle whorl made of limestone. ${ }^{63}$ Spindle whorls may have been deposited as keepsakes or protective amulets symbolic of the home, but they are also significant for their link with spinning and weaving, activities that sometimes carried undercurrents of magic. Burchard of Worms' Corrector (c Iо Iо) suggests a connection between spells and charms and the weaving of cloth:

Have you been present at or consented to the vanities which women practise in their woollen work, in their weaving, who when they begin their weaving, hope to be able to bring it about that with incantations and with their own actions that the threads of the warp and the woof become so intertwined that unless [someone] makes use of these other diabolical counter-incantations he will perish totally? If you have ever been present or consented you must do penance for thirty days on bread and water. ${ }^{64}$

The ancient tradition of depositing coins in burials continued into the late Middle Ages, although its incidence is relatively rare (Tab 3). Coins appear as amulets in brooches from the I Ith century and may have been included with medieval burials for their apotropaic value. ${ }^{65}$ Single coins of silver were sometimes deposited in or near the mouth or eyes, for example: a silver half penny of Edward III was recovered from near the head of a skeleton that was buried to the west of the church at Taunton Priory and graves from the parish cemetery at Ballyhanna included pennies dating to the reign of Edward I.

\footnotetext{
${ }^{63}$ Rahtz i 969, 86-8.

${ }_{64}$ Meaney ig8 I, I85; McNeill and Gamer i 965, 330.

${ }^{65}$ Hinton 2005, I 59; Merrifield i $987,67$.
} 
TABle 3

SINGLE AND DOUBLE DEPOSITS OF COINS OF MEDIEVAL DATE ASSOCIATED WITH LATER MEDIEVAL BURIALS IN BRITAIN

\begin{tabular}{|c|c|c|c|c|}
\hline Site & Date & Age and sex & Comments & Source \\
\hline $\begin{array}{l}\text { Parish church of St } \\
\text { Martin, Wharram } \\
\text { Percy (North } \\
\text { Yorkshire) }\end{array}$ & $\begin{array}{l}\text { Cut halfpenny of } \\
\text { Henry II ( I I } 58-80 \text { ); } \\
\text { I } 2 \text { th century }\end{array}$ & $\begin{array}{l}\text { Adult female, aged } \\
2 \mathrm{I}-4\end{array}$ & Burial G443 & $\begin{array}{l}\text { Mays et al } \\
2007,303, \\
340\end{array}$ \\
\hline $\begin{array}{l}\text { Tavistock Abbey } \\
\text { (Devon) }\end{array}$ & $\begin{array}{l}\text { Coin of Edward I } \\
(\text { I } 28 \mathrm{I}-2)\end{array}$ & Adult male & $\begin{array}{l}\text { North aisle; } \\
\text { priest's burial; } \\
\text { placed near } \\
\text { mouth }\end{array}$ & $\begin{array}{l}\text { Stead I999, } \\
\text { I } 5^{6-7}\end{array}$ \\
\hline $\begin{array}{l}\text { Kirkstall Abbey } \\
\text { (West Yorkshire) }\end{array}$ & $\begin{array}{l}\text { Silver farthing } \\
\text { of Edward IV } \\
(\mathrm{I} 46 \mathrm{I}-83)\end{array}$ & $\begin{array}{l}\text { Unknown; } \\
\text { discovered in Igth } \\
\text { century }\end{array}$ & $\begin{array}{l}\text { Stone coffin; } \\
\text { placed near } \\
\text { head; silver } \\
\text { spoon also } \\
\text { associated }\end{array}$ & $\begin{array}{l}\text { Gilchrist and } \\
\text { Sloane } 2005 \text {, } \\
\text { I I I }\end{array}$ \\
\hline $\begin{array}{l}\text { Sandwell Priory } \\
\text { (West Midlands) }\end{array}$ & $\begin{array}{l}\text { Silver halfpenny of } \\
\text { Edward III (I } 335^{-} \\
43) ; \text { i } 4 \text { th-century } \\
\text { burial }\end{array}$ & Young adult female & South transept & $\begin{array}{l}\text { Hodder I 99I, } \\
84\end{array}$ \\
\hline $\begin{array}{l}\text { St Augustine's } \\
\text { Abbey, Canterbury }\end{array}$ & $\begin{array}{l}\text { Silver halfpenny; } \\
\text { burial dated }\end{array}$ & Adolescent & $\begin{array}{l}\text { South of the } \\
\text { nave }\end{array}$ & $\begin{array}{l}\text { Sherlock and } \\
\text { Woods i988, } \\
66\end{array}$ \\
\hline $\begin{array}{l}\text { Holyrood Abbey, } \\
\text { Edinburgh (City of } \\
\text { Edinburgh) }\end{array}$ & $\begin{array}{l}\text { Silver penny of } \\
\text { Edward I } \\
\text { (c I } 300-\mathrm{IO} \text {; worn } \\
\text { and clipped) }\end{array}$ & Female & $\begin{array}{l}\text { Found close to } \\
\text { hip; pathology: } \\
\text { osteochondritis } \\
\text { dissecans }\end{array}$ & $\begin{array}{l}\text { Bain i } 998, \\
\text { Io6 I, I } 072\end{array}$ \\
\hline $\begin{array}{l}\text { St Giles' Cathedral, } \\
\text { Edinburgh }\end{array}$ & $\begin{array}{l}\text { Five coins from } \\
\text { four graves (James } \\
\text { III, IV, V, c } \\
\text { I } 465^{-1526)}\end{array}$ & $\begin{array}{l}\text { Two female; one } \\
\text { older juvenile; one } \\
\text { middle-aged, sex } \\
\text { unknown }\end{array}$ & $\begin{array}{l}\text { S choir aisle; } \\
\text { one coin bent; } \\
\text { pathology: } \\
\text { rickets }\end{array}$ & $\begin{array}{l}\text { Collard et al } \\
2006\end{array}$ \\
\hline $\begin{array}{l}\text { Taunton Priory } \\
\text { (Somerset) }\end{array}$ & $\begin{array}{l}\text { Coin of Edward III } \\
\left(1344^{-52}\right)\end{array}$ & Not yet reported & $\begin{array}{l}\text { Coffin also } \\
\text { contained } \\
\text { hearth ash }\end{array}$ & $\begin{array}{l}\text { Richard } \\
\text { McConnell } \\
\text { pers comm }\end{array}$ \\
\hline $\begin{array}{l}\text { Ballyhanna parish } \\
\text { church (Co Donegal) }\end{array}$ & $\begin{array}{l}\text { Silver long-cross } \\
\text { pennies of Edward } \\
\text { I }(\mathrm{I} 280-\mathrm{O})\end{array}$ & Not yet reported & $\begin{array}{l}\text { From } \\
\text { cemetery }\end{array}$ & $\begin{array}{l}\text { Ó Don- } \\
\text { nchadha } \\
2007,9\end{array}$ \\
\hline $\begin{array}{l}\text { Merton Priory } \\
\text { (Greater London) }\end{array}$ & $\begin{array}{l}\text { Two coins of } \\
\text { Edward IV } \\
(1465-76)\end{array}$ & Elderly male & $\begin{array}{l}\text { Wooden } \\
\text { coffin; placed } \\
\text { near shoulder }\end{array}$ & $\begin{array}{l}\text { Miller and } \\
\text { Saxby 2007, } \\
233\end{array}$ \\
\hline $\begin{array}{l}\text { Hatch parish church } \\
\text { (Hampshire) }\end{array}$ & $\begin{array}{l}\text { Two coins of } \\
\text { Edward I ( I 280-- } \\
\text { I } 300)\end{array}$ & Young male & $\begin{array}{l}\text { Two silver } \\
\text { farthings near } \\
\text { neck }\end{array}$ & $\begin{array}{l}\text { Fasham and } \\
\text { Keevil i } 995, \\
345^{-5} \text { I }\end{array}$ \\
\hline Whithorn & $\begin{array}{l}\text { Two silver pennies } \\
\text { of Henry III } \\
(\text { ( } 248-\text { I } 250)\end{array}$ & N/A & $\begin{array}{l}\text { Described as } \\
\text { accidental } \\
\text { losses }\end{array}$ & $\begin{array}{l}\text { Hill } 1997, \\
345^{-5}{ }^{\mathrm{I}}\end{array}$ \\
\hline $\begin{array}{l}\text { St James's Priory, } \\
\text { Bristol (Avon) }\end{array}$ & $\begin{array}{l}\text { Two coins of } \\
\text { Richard I ( I I 89-99) }\end{array}$ & Mature male & $\begin{array}{l}\text { Folded and } \\
\text { placed at each } \\
\text { shoulder; also } \\
\text { associated with } \\
\text { jet pendant }\end{array}$ & $\begin{array}{l}\text { Jackson 2006, } \\
99 \text {, I } 33\end{array}$ \\
\hline
\end{tabular}


Cases where two coins were placed near the mouth or shoulders of the corpse, and where coins were bent before being placed in the grave, indicate distinctive rites. For example, a bent coin comes from the grave fill of a juvenile buried at St Giles' Cathedral in Edinburgh; this individual also had a leafshaped pendant found by his or her right side. Medieval accounts of miracles at English shrines well document coin-bending. The bending of a coin represented a contract with the saint, a promise to make a journey of pilgrimage to their shrine, undertaken as part of a healing charm. The coin was held over a sick or injured person and bent while invoking the name of the saint. Coins folded in this manner have been recovered from medieval religious sites including Glastonbury Tor (Somerset), Jarrow and Battle Abbey (East Sussex). ${ }^{66}$

The act of coin-bending bears comparison both with the folding of textual amulets (discussed above), and with the folded, medieval lead pilgrim badges and tokens that have been recovered from the River Thames. ${ }^{67}$ The action of bending or breaking an object may have been integral to the magic rite. There is a cross-cultural tendency to fold or knot amulets to capture the magical efficacy of their material, or for the magic potency to be contained in receptacles such as bags or boxes. ${ }^{68}$

In addition to having been used traditionally as amulets in conversionperiod graves, rings, beads and coins are noteworthy in that these small objects are round or spherical, and easily placed in the hand or mouth of the cadaver. Don Skemer has commented on the significance of the use of circles in pseudoSolomonic magic after the I 2th century. Magic amulets often took the form of circles, including birth-girdles, rings, seals, coins, discs and badges. ${ }^{69}$ To this list may be added papal bullae and spindle whorls, as round amulets that were in both domestic and mortuary use.

\section{MATERIALITY: THE OGGULT POWER OF NATURE}

Medieval 'natural magic' was based on the belief that some natural objects possessed occult virtues or produced a marvellous effect. Their special properties derived from the natural order and their power did not require the aid of spirits. ${ }^{70}$ The choice of objects and natural substances deposited in graves depended on the inherent properties of their materials: stones, plants and animal parts possessed occult materiality. ${ }^{71}$

Archaeologists seldom consider animal parts found in Christian cemeteries as deliberate deposits, but significant associations are sometimes reported. Almost half of the medieval graves excavated at Jarrow contained pieces of

\footnotetext{
${ }^{66}$ Finucane 1977, 94-5; Duffy i 992, г 83; Merrifield ı987, 9 I.

67 Merrifield I 987 , I09-1 2.

${ }_{68}$ Paine 2004, 7.

${ }^{69}$ Skemer 2006, I I 7-I 8, FN I 25.

${ }_{70}$ Page 2004, I 8.

${ }^{71}$ Archaeological use of the term materiality emphasises the values that are placed on fabricated things and how physical engagement with the material world shapes cultural experience. The medieval concept of occult power reinforces Tim Ingold's argument that archaeological definitions of materiality should consider not simply the potential agency of objects but also the inherent properties of their materials (Ingold 2007).
} 
animal bone or shell. While most of this faunal material is likely to have been intrusive and associated with middens, three medieval burials contained complete animal jaws (two of cattle and one of pig) that were noted as possible deliberate grave inclusions. ${ }^{72}$ Animal teeth were included as amulets in conversion-period burials; for example, beaver tooth pendants were associated with women and children. ${ }^{73}$ Boar tusks were included in Christian graves, including one from the monastic cemetery at Wearmouth (County Durham) (placed with an adult of unknown sex) and another at St Oswald's, Gloucester, dating to the IIth century; the tusk was placed near the right shoulder of a female who was buried in a charred coffin. At Whithorn many graves dating to the $13^{\text {th }}$ to $5^{\text {th }}$ centuries contained both cattle teeth and white pebbles. ${ }^{74}$ Animal parts found in direct proximity to the body may be indicators of healing magic: a strong candidate is a rectangular lead sheet $(\mathrm{c} 2 \mathrm{I} 6 \times \mathrm{I} 25 \mathrm{~mm})$ containing brown animal hair, applied to the lower leg of an adult male buried in the cemetery of St Mary Spital (Fig 4). If this instead contained human hair, the lead sheet may represent demonic magic intended as a love token or curse, employing exuviae of the targeted victim.

Fossilised animals were sometimes included as amulets in conversion-period graves, in particular echinoids or fossilised sea urchins composed of flint. There are only two examples reported from later medieval burials in Britain, and both come from infants' graves. An echinoid comes from the Jewish cemetery at Winchester (Hampshire), in use between II 77 and I290. The excavated area was reserved for children, with infants representing 48 out of 88 interments. One infant had a fossil sea urchin placed near the skull. This is likely to have been

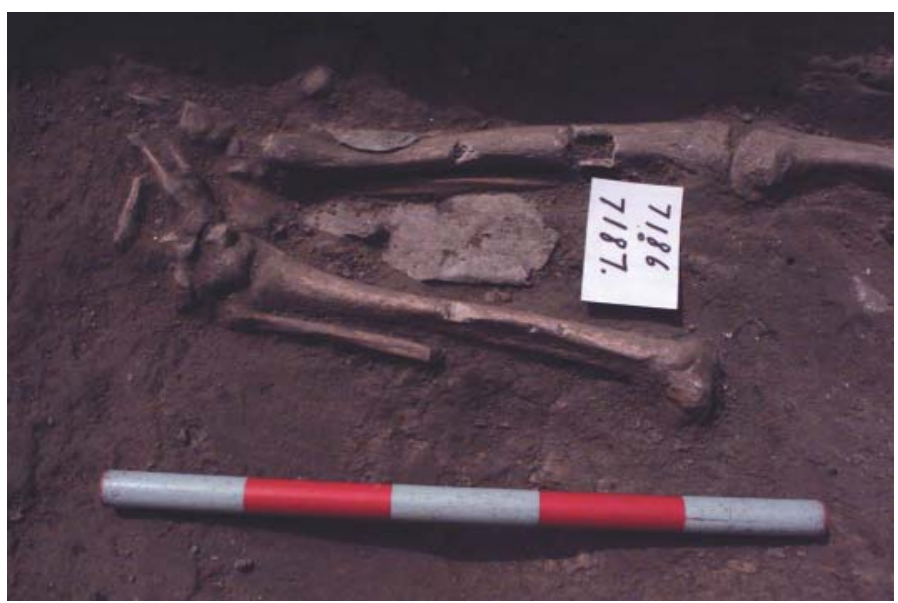

72 Cramp 2005, 259.

${ }_{73}$ Meaney i 98 I, I $35^{-8 .}$.

${ }^{74}$ Cramp 2005, 80; Heighway and Bryant I 999, 202, 2 I 4; Hill I $997,472$.
FIG 4

A rectangular lead sheet containing brown animal hair (c 2 I $6 \times$ I $25 \mathrm{~mm})$, applied to the lower leg of an adult male buried in the cemetery of St Mary Spital, London. Copyright and courtesy of Museum of London Archaeology Service. 
associated with a coffined burial: the excavators estimate a high rate of $75 \%$ coffin use for the site, based on the distribution of iron nails. ${ }^{75}$ This argues against the echinoid being an accidental or natural inclusion in the grave. I consider this case significant here as part of an ancient and widespread tradition of collecting fossilised sea urchins for apotropaic use. We find them from conversion-period women's graves and they were commonly displayed in Roman temples in the NW provinces of the Roman Empire. ${ }^{76}$ They were known throughout Europe as 'thunder-stones', believed to be the physical residue of lightning strikes. Their owners kept them in the home or on the person to protect from thunder and lightning, a belief perhaps resulting from the fact that they are most commonly found in the soil after rain. ${ }^{77} \mathrm{~A}$ fossil (species not reported) comes from the I 2th-century grave of a young child at the parish church of Wharram Percy, aged $1.5^{-2}$ years at death. ${ }^{78}$

Plant material recorded from inside medieval coffins includes moss, heather, rushes and wood shavings used as linings or as pillows for the corpse, or as wrappings for the body. Mourners carefully placed plants on an individual buried within a coffin to the south of the choir at St Nicholas, Aberdeen: seeds and insects were recorded in an area around the spine. ${ }^{79}$ Sometimes people placed timber crosses (and rods discussed above) with medieval corpses, and the frequent selection of the wood of ash and hazel for this purpose may emphasise the powers attributed to these trees. At the Benedictine priory of St Mary Sandwell, waterlogging encouraged the exceptional preservation of four examples of a cross placed vertically behind the head of the corpse. A flanged cross of ash was deliberately broken before it was positioned behind the head of a child, aged 6-io years old. The unusually large skull suggests that the child may have been hydrocephalic, and the wood of the ash may have been chosen for the tree's inherent powers. Ash was regarded as a healing tree in Britain: up to the late i 8th century it was used in a ritual of sympathetic magic to heal rupture or weak limbs in children. ${ }^{80}$

Numerous stones were used for healing and protection, combining ancient indigenous traditions with Classical knowledge of gems recorded by Solinus and Pliny. Lapidaries, books explaining the powers of particular stones, were especially popular from the I 2 th century onwards, and may have contributed to the practice of using ornamental gemstones both for costume and for encrusting the reliquaries of saints. The late-I I th-century Book of Stones (De Lapidus) by Bishop Marbode of Rennes described 6o stones and was well known and frequently copied. The powers of particular stones were linked explicitly to Christian texts, such as the 12 stones of the Apocalypse. ${ }^{81}$ Mainstream medicine used gems,

\footnotetext{
${ }^{75}$ Winchester Museums Archaeology Service, Mews Lane I995 Archive; Gilchrist and Sloane 2005, 246, I I 4 .

${ }_{76}$ Meaney i 98 I, I I 7; Eckardt 2003, 42.

77 Oakley i 965 .

${ }^{78}$ Mays et al 2007, 270, 303 .

79 Aberdeen City Archaeology Unit 2007, i 6

${ }^{80}$ Egan in Hodder i 98 I, I I 3; Mabey r 996, 326.

${ }^{81}$ Evans 1922; Evans and Serjeantson I 933.
} 
linking them to the theory of the humours. For example, sapphires were a cold stone to use for the treatment of excessive bodily heat, ulcers and ailments. This perhaps explains the relatively common occurrence of sapphire rings in the graves of high-ranking ecclesiastics: we know of at least I2 sapphire rings in bishops' burials. ${ }^{82}$

Medieval lapidaries compared white and clear stones to water, and linked them with imagery of the Apocalypse, for example the description of the holy Jerusalem in the Revelation of St John (2 I: I I): 'her light was like unto a stone most precious, even like a jasper stone, clear as crystal'. Scraped in water, the white stone was believed to protect from flying venom, lightning and thunder. ${ }^{83}$ The apotropaic use of crystals may account for the unusual find of a rock crystal from a grave at Rhuddlan (Denbighshire). This was found together with two coins of I092-95, all contained in a leather bag or purse, placed near the left thigh of a male buried in the first phase of the Norman church at Ysgol-YCastell. This man's grave received special elaboration: the grave cut was lined with lumps of mortar and limestone, and a charred wooden object was deposited; a layer of pink sand was spread over this material, and finally his body was placed in the grave. ${ }^{84}$ Jewellery worn to the grave also incorporates crystals: Abbot John Dygon buried at St Augustine's Abbey, Canterbury in I5Io, wore a gilded copper-alloy ring with a rock-crystal setting. ${ }^{85}$

The most widespread mortuary use of stones is the rite of placing white granite or quartz pebbles in the grave or in the hand or mouth of the corpse. The inherent physical properties of quartz are likely to have given it occult value. Quartz is piezoelectric, so that when struck or rubbed together it produces a faint glow (triboluminescence). We know of medieval examples of pebbles placed in the mouth from English parish churches including four from St Nicholas Shambles, Greater London, and one from Raunds (Northamptonshire). Examples also come from the religious houses of St James, Bristol, St Mary Stratford Langthorne, St Mary Graces, Greater London, and from the lay cemetery at Worcester Cathedral Priory. ${ }^{86}$

White, beach-rolled quartz pebbles were commonly included in burials in Ireland, Scotland and the Isle of Man, and in these regions people used them as prayer beads or counters at holy wells up to the 20 th century. ${ }^{87}$ Painted pebbles were sometimes included in Pictish burials, and Adomnán's 7 th-century Life of St Columba attests the use of white stones for healing. They occurred in early and later medieval graves at St Ethernan, Isle of May (Fife), in several later medieval and post-medieval graves at the women's cemetery on Iona (Argyll and Bute), and they were widespread in graves at Whithorn, with I,794 pebbles collected from medieval graves of the I $3^{\text {th }}$ to mid-I $5^{\text {th }}$ centuries, some

\footnotetext{
${ }^{82}$ Kieckhefer I989, I03; Hinton 2005, I 87.

${ }^{83}$ Evans I 922, 52.

${ }^{84}$ Quinnell and Blockley i 994, 79; Boon i 994, г64.

85 Thorn I98I.

${ }^{86}$ Gilchrist and Sloane 2005, 78, I 44-5.

${ }^{87}$ Lebour i 9 I 4 .
} 
of which also had coins and cattle teeth deposited. Approximately two-thirds of the I,275 inhumations excavated at the parish cemetery of Ballyshannon record them, deliberately placed in the hands of the corpses. ${ }^{88}$ This rite was more geographically widespread in early-medieval burials, including Wearmouth, Llandough (The Vale of Glamorgan), Kellington (North Yorkshire), Capel Maelog (Powys) and Barnstaple (Devon). ${ }^{89}$

But the occurrence of quartz pebbles in British mortuary contexts pre-dates Christianity: they are also found in association with prehistoric burials and monuments, such as kerb cairns and recumbent stone circles. From the prehistoric period up to the later medieval, they are particularly concentrated in the Isle of Man, Wales, Scotland and Ireland. Chris Fowler has argued that the substance of quartz as a raw material carried the symbolic associations of the seashore and mountains. Prehistoric people may have regarded it as generative or transformative, with its incorporation in mortuary contexts conveying the symbolism of water and new beginnings. ${ }^{90}$ To medieval Christians, water also symbolised rebirth through baptism, and the light-emitting properties of quartz may have added connotations of purity and salvation through the cleansing fires of purgatory.

Jet - a hard, velvet-black form of coal — was polished and carved into beads, crosses, rosaries and croziers that were deposited in the grave (Tab 4). Its intense black hue may have connected jet with death, just as Victorians used it in mourning jewellery. But jet was also traditionally known for providing protection from snakes, as indicated both by Pliny and Bede; this quality may have been especially useful to the soul entering purgatory, the serpent's lair. ${ }^{91}$ Marbode recorded that the fumes from burning jet could dismiss the powers of hell, as well as curing a long list of ailments. The Roman physician Galen recommended jet for treating diseases of the womb, closing up wounds and for chronic swelling of the knees. The majority of jet objects from Roman graves were associated with females, and Allason-Jones argues that the substance had special significance for women. ${ }^{92}$ Objects of jet and especially amber (fossilised tree resin) were also common in Anglo-Saxon burials of the $5^{\text {th }}$ to 7 th centuries, and these materials may have been prized initially for their dual physical properties of developing a static charge and emitting a smell when rubbed. The static produced by rubbing pieces of amber or jet together, or with a material such as wool, is sufficient to pick up a light object. The materials of amber and jet share the property of electrostatic induction, which medieval people may have perceived as evidence of the occult power of nature.

\section{ANTIQUities: THE MAgiG SIgNifiGANGE OF ANGIENT ObJEGTS}

A number of later medieval burials contained Roman or more rarely early-medieval items placed on the body or deposited in the grave, including

\footnotetext{
${ }^{88}$ Peter Yeoman pers comm; O’Sullivan I994, 334, 358; Hill I997, 473; Ó Donnchadha 2007, 9.

${ }^{89}$ Cramp 2005, 89; Hadley and Buckberry 2005.

${ }^{90}$ Fowler 2004, i I 6.

${ }^{91}$ Meaney I98I, 7 I.

${ }_{92}$ Allason-Jones I 996, I5, I 7 .
} 
I 40

ROBERTA GILGHRIST

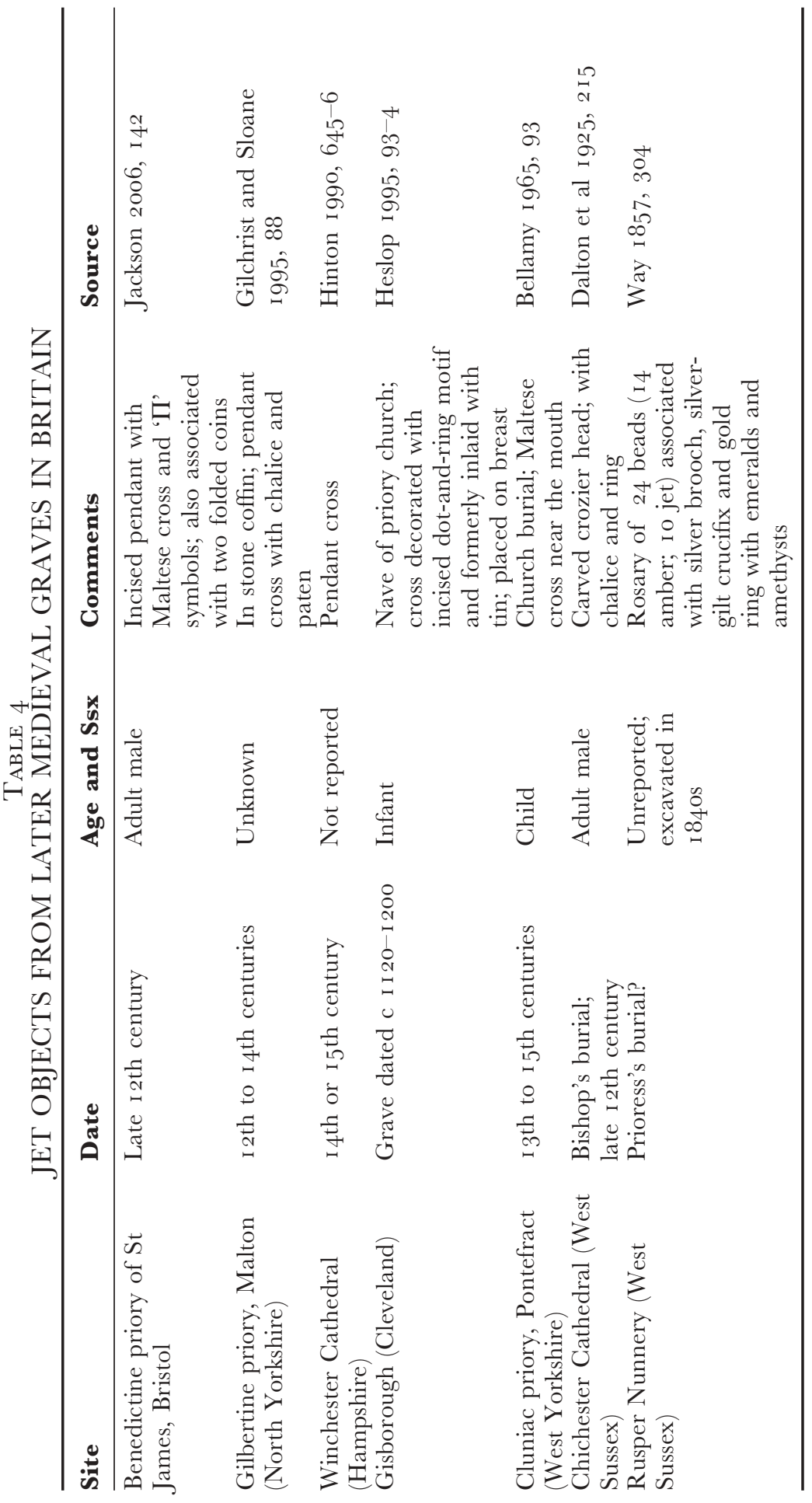


coins, jewellery, beads and fragments of tile or pottery (Tab 5). In several cases these antique items were placed within coffins and in direct contact with the body, arguing against an interpretation as residual items or accidental losses. These medieval examples parallel the Anglo-Saxon custom of including Roman melon beads and pierced Roman coins in burials. Roman burials also sometimes included heirloom items or prehistoric worked flints. ${ }^{93}$ The tradition of placing a single bead with a child's burial, as evidenced at St Bartholomew's, London, existed right across Europe, and folklorists interpret it as an amulet against the evil eye. ${ }^{94}$ The belief that old coins had special healing properties was prevalent into the post-medieval period, suggesting that the apotropaic value of a coin increased with its age. ${ }^{95}$

Archaeologists have interpreted the girdle bags and thread-boxes that sometimes appear in conversion-period female graves as toolkits for healing or divination. These included broken fragments of Roman glass and various items that would have been 'at least one hundred years old' at the time of burial. Meaney argued that these were significant as objets trouvé, unusual objects that were picked up and attributed with the power to bring luck or avert evil. ${ }^{96}$ Roger White has shown that Anglo-Saxons used Roman objects more routinely as grave goods in their inhumations, with bracelets, brooches and coins usually occurring singly in the graves of women and children. ${ }^{97}$ White concluded that they reused Roman artefacts for functional reasons, but Hella Eckardt and Howard Williams have drawn attention to the association of Roman and prehistoric objects and fossils in Anglo-Saxon burials, concluding that their antiquity gave them an apotropaic value. ${ }^{98}$ We see this pattern repeated in the later medieval burials, both in terms of the specific Roman items selected for use as grave goods and in their association with women and children.

Antique cut gems appear in a number of medieval bishops' tombs, reset in finger-rings and worn to the grave. For example, Archbishop Hubert Walter's ring was a green stone with a serpentine creature engraved upon it; its Greek inscription identifies this as a Chnoubis gem of Graeco-Egyptian provenance.

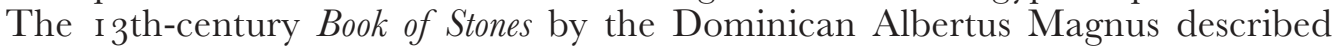
the special properties of images in stones, including antique cameos and intaglios, alongside agates and fossils. Albertus regarded the images or 'pictures' in cut gems as having been naturally created, with celestial powers channelled through astrological images. ${ }^{99}$

\footnotetext{
${ }^{93}$ Eckardt 2003, 42, 44. Worked flints found in association with medieval burials are seldom commented upon, even where they appear to occur with coffined burials, such as two examples from St James, Bristol (Jackson 2006, 79, 8I).

${ }_{94}$ Meaney I98 I, I 93, 2 I 3-I 5, 272; Maguire I 997, I 04 I. Hinton (2005, I 56-60) suggests that cloisonné enamel brooches with tiny beads of glass, dating to the later i oth and I ith centuries, may also have served as talismanic 'eyes' to ward off evil.

95 Gazin-Schwarz 200 I, 272.

${ }_{96}$ Meaney i 989, I o.

${ }_{97}$ White I 988, I 54, I 63, I 65.

98 Eckardt and Williams 2003, I 5O, I63.

${ }^{99}$ Stratford I 982, 87; Albertus Magnus: 'even in stones hardened by vapours, there is impressed upon the material the shape of a man or that of some other species that nature produces' (Wyckoff i 967 , I 27-35).
} 


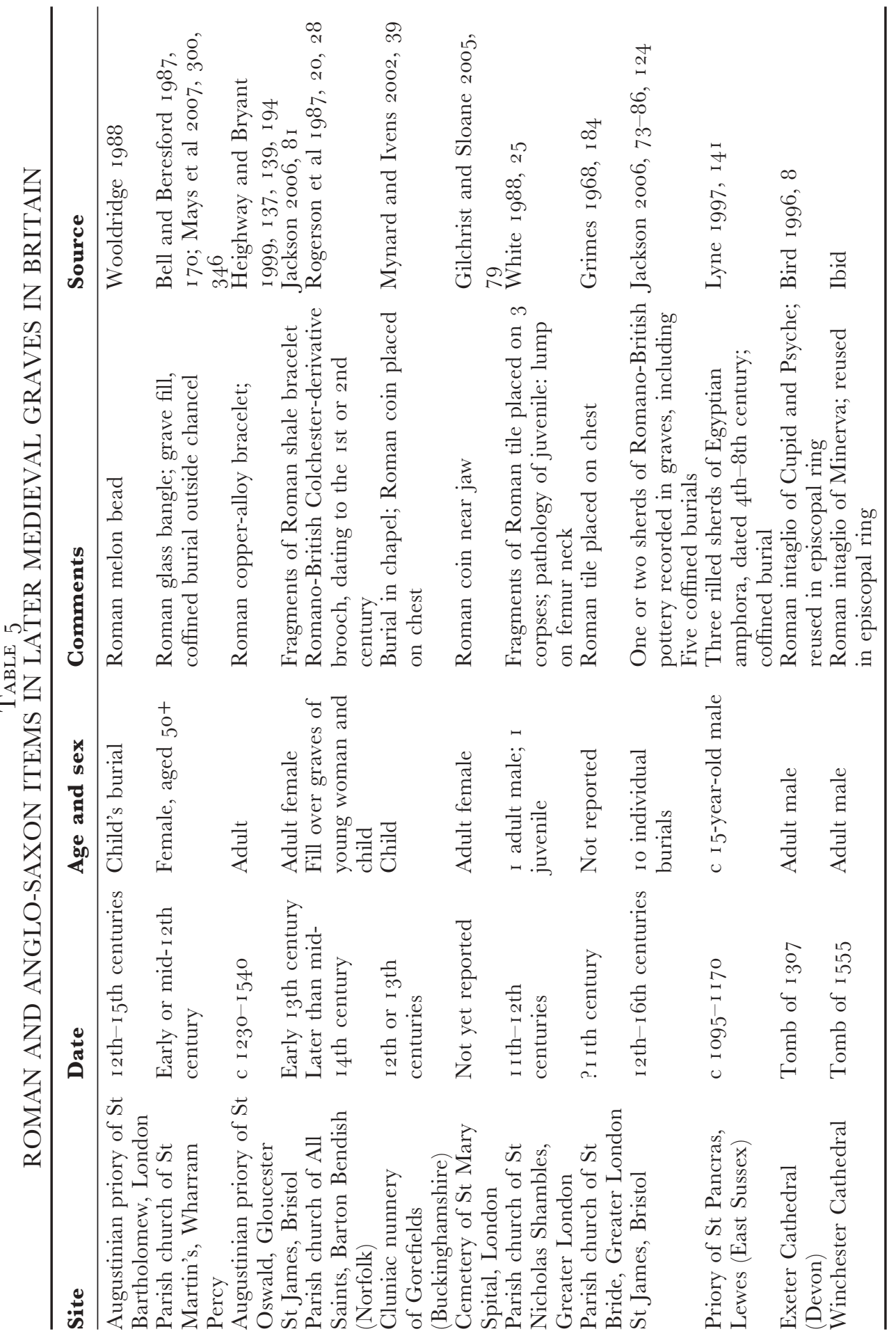


MAGIG FOR THE DEAD?

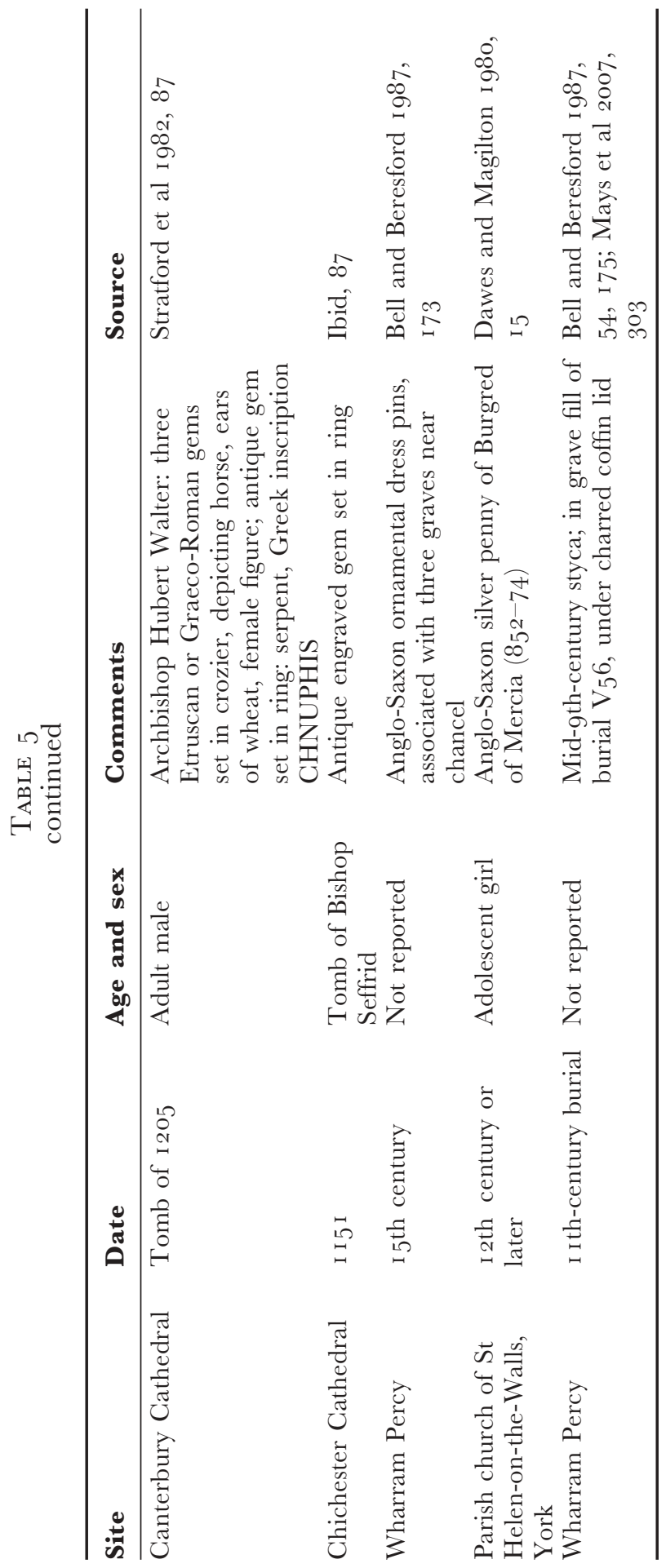


Archaeologists usually discuss heirlooms in terms of artefact biographies, tracing how and why people exchanged, circulated, remodelled or repaired and deposited a particular object, ${ }^{100}$ but the very antiquity of some objects lent them a magical quality, perhaps equivalent to the occult power of natural objects. The significance of these objects seems to be in their antiquity, rather than their status as found objects. These were 'curated' artefacts treasured by both the popular and learned branches of magic, demonstrated by their interment in parish cemeteries and episcopal tombs.

\section{DEMONIG MAGIG?}

Intellectual branches of medieval magic employed complex ceremonies intended to conjure supernatural agents; these spirits could be harnessed for beneficial or malign purposes. Clerical necromancers developed forms of divination that aimed to forecast the future or hidden truths, or to detect criminals, stolen goods or hidden treasure. Some of the items discussed above as possessing occult power were also favoured for divination, notably crystals, stones and rings. ${ }^{101}$ According to the Hermetic Liber de quindecim stellis, crystal was able 'to gather demons and spirits of the dead, and to call winds and know hidden secrets'. ${ }^{102}$

Monastic communities would have been well versed in these forms of learned magic, and two particular burials from religious houses might suggest an effort to communicate with or through the dead. Such practices were certainly known in medieval England: divination from a dead person's body or clothing, 'lest the dead take vengeance, or in order that another in the same house shall die' was condemned in the penitential of Bartholomew Iscanus, Bishop of Exeter ( 1 I 6 I-84), incurring a penance of 40 days. ${ }^{103} \mathrm{~A}$ stone-lined cist dating to the I Ith or I 2th century, excavated outside the Norman apse of Lichfield Cathedral, was lined with plaster and covered over with mortared capping stones, but an opening was deliberately created over the mouth of the entombed priest. ${ }^{104}$ The second example is that of a young male buried in the I $4^{\text {th }}$ century at the Cluniac priory of St Ethernan, Isle of May. His mouth was wedged open with a sheep tibia and a half scallop shell inserted inside. ${ }^{105}$ Diviners sometimes employed sheep bones in their rituals, interpreting the marks on the scapula in particular (spatulimancy). A I $5^{\text {th-century necromancer's }}$ handbook from Munich records another rite, which instructs the master to anoint the right shoulder blade of a ram with oil and place it beneath the handle of a knife; the master then conjures demons who will answer questions through the medium of a virginal boy. ${ }^{106}$

\footnotetext{
100 Kopytoff i 986; Marshall and Gosden eds i 999.

101 Kieckhefer i 997, i I 3, 97

102 Page 2004, 27.

${ }_{103}$ McNeill and Gamer i 965, 350.

104 Nenk et al I995, 24I.

105 Yeoman and James in prep.

106 Kieckhefer I997, I I 3 .
} 
A more widespread medieval burial rite could potentially connect with earlier forms of sorcery that the Anglo-Saxon penitentials condemned. This burial practice involved lining the coffin with ash before placing the corpse into it. There are some $5^{6}$ reported examples from later medieval graves, principally from urban locations in the south of England. ${ }^{107}$ For example, at Taunton Priory, excavations by Context One Archaeological Services recovered two ash burials from a total of 192 complete skeletons: one from inside the church and one from the lay cemetery. The extramural burial has been dated to the mid-I 4 th century through the recovery of a coin from the ash deposit, a silver half penny of Edward III (I344-52) (Figs 5 and 6). At the parish church of St Peter's, Leicester, excavations by the University of Leicester Archaeological Services recorded ten ash burials within a sample of over I, 300 inhumations. Eight of these were from within the church, including one from a possible chapel in the north aisle dated by two floor tiles contained in the coffin, one with the mid-1 $4^{\text {th }}$ century arms of the dukes of Lancaster (Fig 7).

Where the ash from these coffins has been analysed, its composition has included carbonised grain and peas, splinters of burnt bone and eggshell, pottery fragments and wood charcoal; in other words, the ash is likely to represent domestic hearth rakings. Ash linings were used for men, women and children in all types of cemeteries, but have not yet been found in association with a priest's burial. Dated examples suggest a range from the late i 3 th century to the midI $5^{\text {th }}$ century, with a concentration c I300-50. Sixteen examples come from the East Smithfield Black Death cemetery in Greater London (1348-50), suggesting that this rite was especially prevalent during the crisis of the plague, and confirming that it was used for some plague victims. This I 4 th-century practice is distinct from the charcoal burials of the early gth to i 2 th centuries, in which oak charcoal was spread uniformly within the grave cut. Victoria Thompson interprets these earlier charcoal burials as a rite linked with penitence and purity, and connected with the clean ash used for purification in Ash Wednesday ceremonies and in rites for the sick or dying. ${ }^{108}$

It seems plausible that the corpses of plague victims were particularly feared, and that the ash ritual could indicate magic to protect the living by restraining the dangerous dead from walking. It is reminiscent of earlier, exorcistic practices recorded in the books of penance. The 7 th-century Penitential of Theodore states 'He who causes grains to be burned where a man has died, for the health of the living and of the house, shall do penance for five years'. The later Confessional of Egbert prescribes one year of fasting for 'Anyone who burns corn in the place where a dead man lay, for the health of living men and of his house'. Regino of Prüm repeats Theodore's instructions, indicating five years of penance if 'thou hast burnt grains where there was a dead man'. ${ }^{109}$ The composition of

\footnotetext{
107 In addition to 43 listed in Gilchrist and Sloane (2005, I 22), I 3 new examples have been reported: two from Taunton Priory (Richard McConnell pers comm); a plaster-lined grave at Holy Trinity, Buckfast (Devon), radiocarbon dated to the I $4^{\text {th }}$ century (Andrew Reynolds pers comm); and ten from the parish church of St Peter's, Leicester, which went out of use by c I $55^{0}$ (Gnanaratnam 2006a and 2006b). 108 Thompson, 2004, I I 8-22.

${ }^{109} \mathrm{McNeil}$ and Gamer i965, I98, 246, 3 I8.
} 

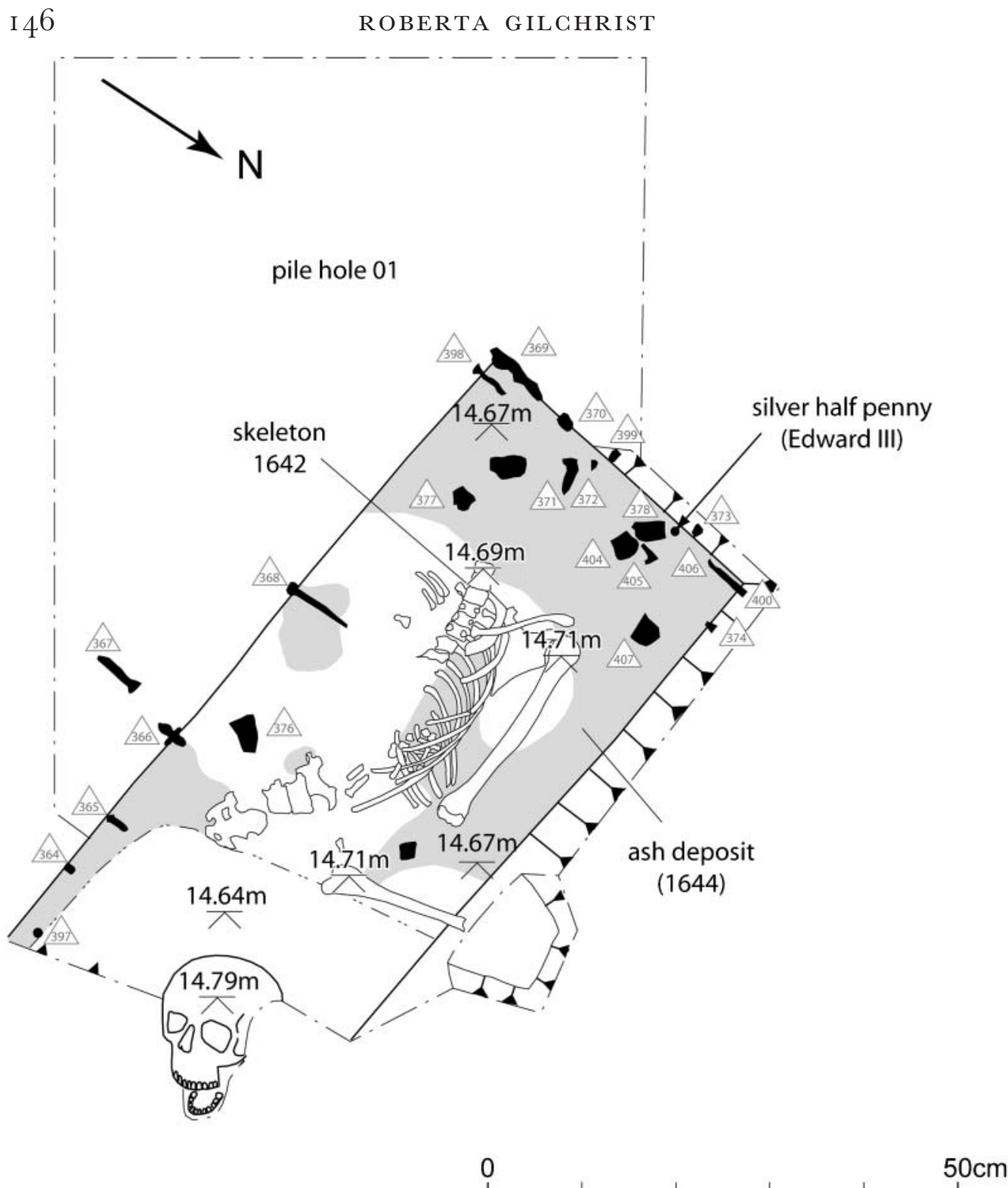

FIG 5

Coffined adult burial containing an ash deposit, located to the south-west of the priory church at Taunton, Somerset (skeleton number I642), in the area of the lay cemetery. Drawing by ECM Gardner, copyright and courtesy of Context One Archaeological Services.

the ash linings indicates general food debris and hearth rakings, and not the remains of burnt grain in particular. Its close association with the Black Death, however, supports interpretation as the residue of a rite intended to purify the house of the deceased, and perhaps to stop them from returning home as a 

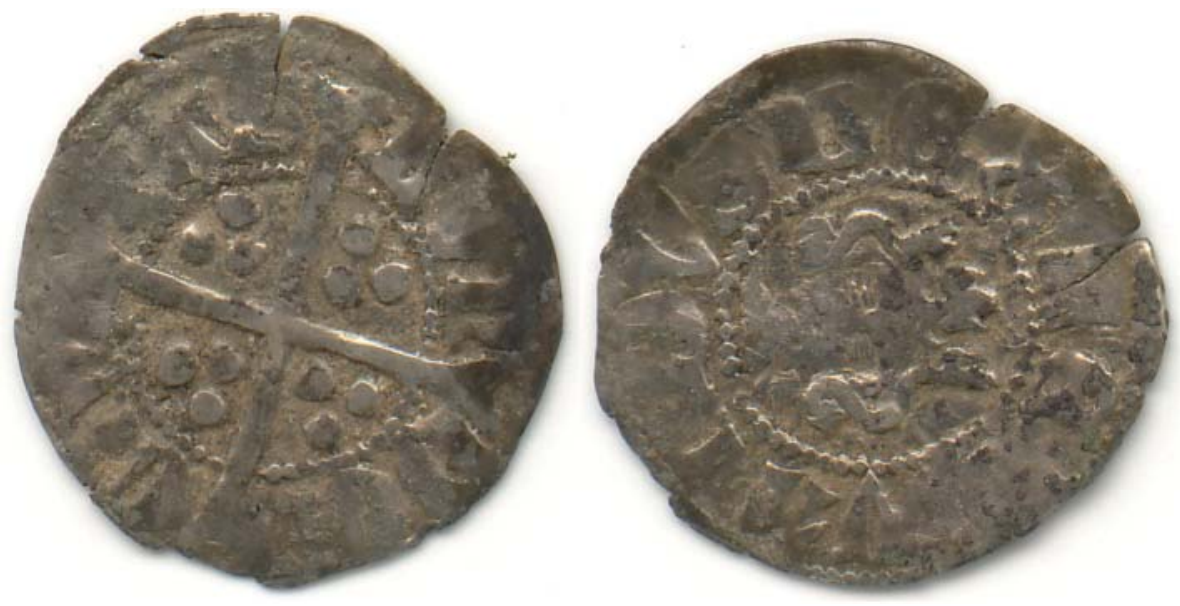

FIG 6

Silver half penny of Edward III (I $344^{-52}$ ) from an ash burial excavated to the south-west of the priory church at Taunton, Somerset (skeleton number I642). The location of the coin in relation to the articulated remains suggests that it may have been associated with the skull. Copyright and courtesy of Context One Archaeological Services.

revenant (the walking 'undead'). Folklore from some parts of Europe, such as Brittany (France), includes the belief that the dead would return home from the grave to seek the warmth of the hearth. ${ }^{110}$ The $\mathrm{I} 4^{\text {th }}$ century may have witnessed some revival of a popular tradition that involved burning grain in the hearth and then thoroughly cleaning up the rakings, before depositing the resulting ash as a lining in the coffin.

\section{INTENTION AND AGENGY: MAGIG FOR THE DEAD}

The typology of objects and materials developed in this analysis has attempted to identify healing charms and amulets, and to distinguish the use of natural and demonic magic in the context of medieval burials. To understand fully the meanings behind these rites we must consider whether this magic was intended to heal, protect or conjure the dead. Who was the magic directed towards, and who were its practitioners? How did these mortuary rites relate to orthodox religious practices and to forms of popular and learned magic? The identity of the recipients of this magic is the key to understanding the meanings behind these mortuary rites.

Amuletic items in conversion-period graves of the 7 th to gth centuries, such as waist-bags, boxes, fossils, Roman coins and animal teeth, have been used to identify the female practitioners of magic, the family healers and 'cunning women', who were buried with the personal tools of their craft. ${ }^{111}$ Magical items 


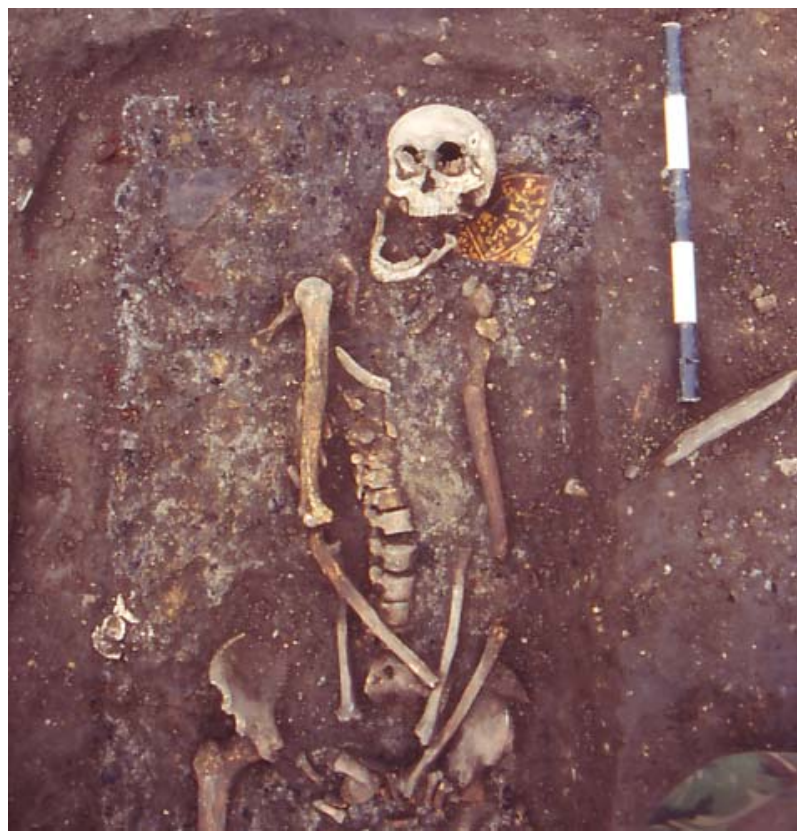

FIG 7

Ash-lined coffin burial from the parish church of St Peter's, Leicester, located in a possible chapel in the $\mathrm{N}$ aisle of the church. Two floor tiles were deposited in the coffin, one with the mid-I $4^{\text {th }}$ century arms of the dukes of Lancaster. Copyright and courtesy of University of Leicester Archaeological Services.

in graves of the IIth to I $5^{\text {th }}$ centuries were placed also with infants and children, and where they occur with adults, equally with males and females. These grave goods do not represent the personal possessions of the deceased, nor do they necessarily mark them out as practitioners of magic. Children are under-represented demographically in excavated cemeteries of all types, and it is therefore noteworthy that their graves make up a disproportionate number of those interpreted here as being linked with magic. With the exception of the deposition of bullae, children were the recipients of the full range of rites described here. This is a strong indication that the magic was intended to protect the dead, rather than to conjure demonic spirits or to guard against them. Medieval stories of revenants usually described adult males who had lived an evil life and had come to a bad end, rendering their corpses prone to demonic possession. Excepting unbaptised infants, children did not possess the accumulation of sin generally connected with revenants. ${ }^{112}$

People regarded infants and young children as needing special protection against malign forces such as the evil eye: the power to inflict death, disease or destruction by a glance. Although today we associate this belief with eastern Mediterranean traditions, it was widely held by Christians and Jews throughout Europe. Its biblical precedents connected it with the sin of envy: 'Is thine eye evil because I am good?' (Matt. 20: I5), and 'Eat not the bread of him that 
hath an evil eye' (Prov. 23: 6-7). Items such as beads were worn to distract the evil eye, or perhaps to reflect it, since beads somewhat resemble eyes. ${ }^{113}$ The notion that surrogate 'eyes' could deflect malevolence might be one reason why anthropomorphic coins (and bullae) were included in burials. I suggest that the Roman melon bead, the fossil echinoid, and the Roman and Anglo-Saxon coins that were buried with infants and children were placed as protection against malevolent forces, and perhaps to deflect the evil eye.

The charms placed with the dead were not merely protective; some were associated specifically with healing. They were occasionally placed with individuals whose afflictions left a pathological signature on the skeleton: a middle-aged woman at St Nicholas, Aberdeen, and two others from St Giles' Cathedral, Edinburgh, suffered from adult rickets and were interred with a religious badge, a timber rod and coin, respectively. A woman buried at Holyrood Abbey, Edinburgh, with a silver penny near her hip, suffered from osteochondritis dissecans, a condition that would have affected the circulation and mobility in her legs and feet; and an adult male at Raunds, buried with a pebble in his mouth, had suffered from poliomyelitis in his youth, and later developed tuberculosis. ${ }^{14}$ The Anglo-Saxon penitentials and later hagiographic and theological writings indicate a belief that a dead body might heal. In the early i ith century, Burchard of Worms condemned rites intended to heal corpses as a form of sorcery: 'Hast thou done or consented to what some people do to a slain man when he is buried? They give a certain ointment into his hand, as if by that ointment his wound can be healed after death, and so they bury him with the ointment. If thou hast, thou shalt do penance for twenty days on bread and water'. ${ }^{15}$ But the premise that the dead could be healed was rapidly integrated in the cult of saints' relics. Lives of the saints included details of their holy bodies remaining incorrupt after burial, and their injuries or infirmities sometimes healed miraculously after death. For example, a I 2th-century account of the exhumation and translation of the body of St Etheldreda emphasised that a tumour on her neck had healed after burial. ${ }^{116}$

In her study of the body in western Christianity, Bynum concluded that souls were regarded by medieval people as 'somatomorphic': disembodied spirits could suffer bodily tortures, and the condition of the corpse in the grave reflected the fate of the soul in purgatory. The physical remains of the dead 'manifest corporeally on earth the state of their souls in paradise'. ${ }^{117}$ Archaeological evidence for medical items interred still adhering to the corpse confirms popular belief in the sustained connection between the soul and the body, including hernia trusses and copper-alloy plates used to heal and protect joint

\footnotetext{
113 Simpson 2000, 285-7; Meaney i 98 I, 209.

114 Boddington I 996,42 .

115 McNeill and Gamer i 965,334 .

116 This reworks the account in Bede (Historia Ecclesiastica IV, I9) in which the physician Cynifrid testifies that the tumour, and his incision made to drain it, had completely healed during the $\mathrm{I} 6$ years in which the saint's body was buried.

117 Bynum i 995, 206, 296.
} 
injuries or disease. ${ }^{118}$ I suggest that in common with the magico-medical charms placed with the dead, these therapeutic devices were intended to treat or heal the corpse while it was in the grave, in preparation for the corporeal resurrection at the day of judgement.

The majority of cases discussed here seem to represent charms or natural magic harnessed to protect or heal the dead, but the ash burials may be a remnant of earlier rites of sorcery that were intended to safeguard the living from the dead (Fig 8). The placement of hearth ash in the coffin could simply represent a gesture of home and comfort offered to a loved one, ${ }^{119}$ but two factors argue against this. First, there is the high incidence of ash burials in the Black Death cemetery at East Smithfield, London, representing i 6 out of 56 reported examples of this practice. Second, there are the earlier references in the penitentials to rites of grain-burning that were undertaken to protect the living and the house, condemned by churchmen as the practise of sorcery. The ash burials

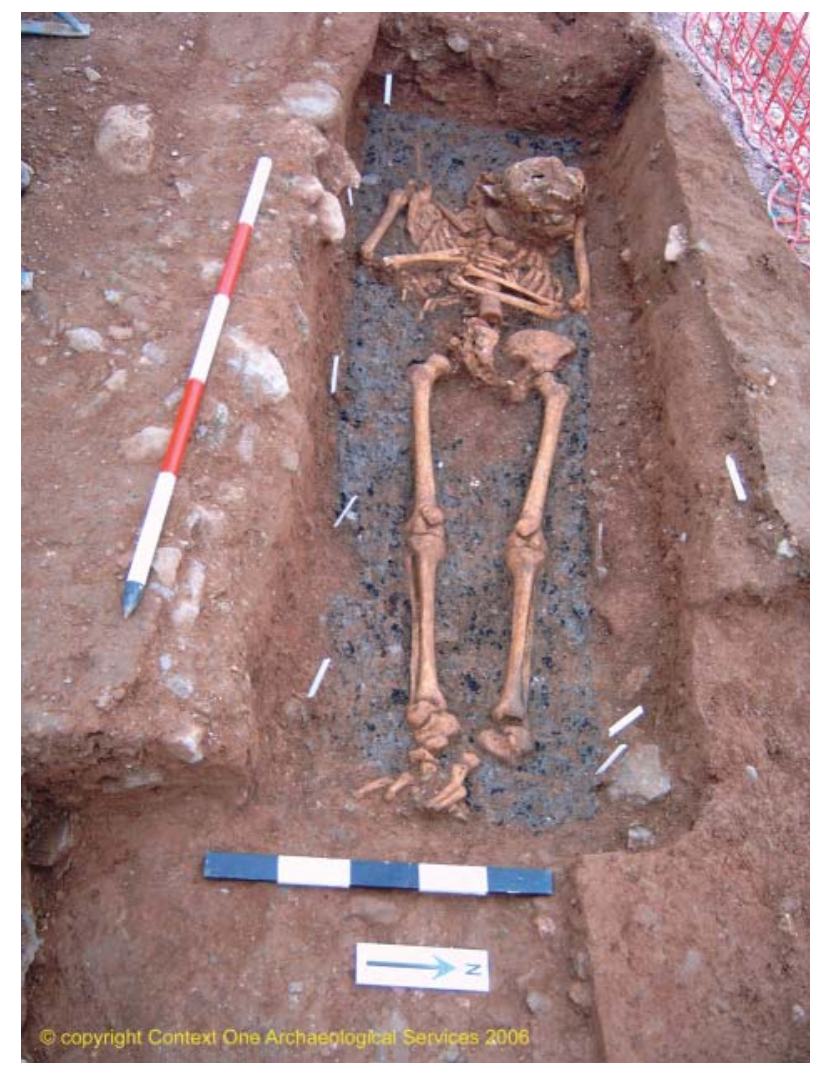

FIG 8

Ash-lined coffin burial of an adult from the nave of the priory church at Taunton, Somerset (skeleton 9o8), associated with burnt animal bone and a ?shroud pin. Copyright and courtesy of Context One Archaeological Services. 
may indicate the revitalisation of a folk custom in the I 4 th century, when the crisis of repeated epidemics intensified fear of the dead. The lack of correlation with priests' burials suggests no link between this rite and learned magic or divination. Graves accompanied by papal bullae also had limited currency, dating to the I $4^{\text {th }}$ and I $5^{\text {th }}$ century. In one example these two practices converged: an ash burial in the nave of the parish church of St Peter's, Leicester, contained a bulla of Innocent VI ( I 352-62). ${ }^{120}$ Although some parallel is observable with the earlier apotropaic use of coins and medallions, the terror of the Black Death may have stimulated the deposition of bullae as amulets. ${ }^{121}$

The ash burials may signal some element of continuity with early-medieval magic, and so too does the selection of traditional amulets such as coins, beads and spindle whorls for use as grave goods. These items repeat the choice of amulets placed in conversion-period graves: the increased use of amulets during the conversion may have been intended specifically to protect the integrity of the corpse for Christian resurrection. Medieval magic accommodated earlier customs to include certain natural materials and ancient objects in graves. The placement of antique items in medieval burials, particularly Roman coins and jewellery, repeated the Anglo-Saxon preference to include Roman items in the graves of women and children. Quartz and jet were traditional grave goods, and their piezoelectric and electrostatic qualities must have enhanced their value to medieval people as natural materials possessing occult power.

The placement of quartz stones or pebbles in the grave, or in the mouth or hand of the corpse, is perhaps the best example of the hybridity of pagan and medieval Christian magic. Their placement in prehistoric and early-medieval graves may have symbolised water and regeneration; these traditions were easily absorbed in Christian beliefs, such as the efficacy of water in cleansing sin, particularly through baptism. Transparent stones such as quartz developed associations with the Apocalypse, making it particularly relevant as a grave good for the Christian dead. There was an explicit link with the Apocalypse, when all dead souls would rise for judgement: 'To him that overcometh will I give ... a white stone, and in the stone a new name written, which no man knoweth saving he that receiveth it' (Revelation II: I7). ${ }^{122}$ In the medieval Christian context, these clear or white stones symbolised rebirth through the processes of baptism, death and resurrection.

Can we determine who was responsible for performing this 'magic' for the dead? The objects deposited in direct contact with the corpse are the strongest indicators: items placed in the mouth or hand, on the breast, or within the

\footnotetext{
120 Gnanaratnam 2006a; 2006b.

${ }^{121}$ Burial practices do not appear to have changed significantly because of the Black Death. In addition to the possible correlation of the bullae and ash burials, a peak in coffin use may be indicated (Gilchrist and Sloane 2005, 222). David Hinton has commented that there was little impact on material culture resulting from the Black Death: apotropaic jewellery, talismanic inscriptions and rosaries were all common before the mid-I 4 th century (Hinton 2005, 23I).

122 The folklorist Lebour first noted this ( I 9 I 4 ).
} 
shroud or coffin. The essence of their apotropaic or healing power relied on intimate contact with the skin. The placing of these items would have taken place during preparation of the body, when it was washed and dressed or wrapped in a shroud. In a secular context, women of the family, or perhaps a midwife, prepared the body in the home, while the monastic dead would have been prepared in the infirmary. ${ }^{123}$ Healing charms were part of the popular tradition of folk magic, routinely performed by women in the care of their families, by herbalists and midwives, and occasionally by academic practitioners such as surgeons and physicians. ${ }^{124}$ Unlearned, female practitioners worked more closely with natural objects that were attributed with occult powers, in contrast with the more complex rituals of demonic magic that characterised the male 'clerical underworld'. ${ }^{125}$ Perhaps only two burials discussed here show any affiliation with the clerical practices of divination, and there is little evidence that demonic magic was employed in association with medieval burial rites.

There was a long folk tradition of women using charms and sympathetic magic in caring for their families, and it may be suggested that their rôles as healers extended to nurture of the dead. The over-representation of children in the sample may comment on the significance of family bonds: perhaps mothers or grandmothers used charms to protect the young as the most vulnerable of the dead. Through their family roles, women had access both to the corpse, and to powerful materials such as herbs, hearth ash and spindle whorls. But magic for the dead was not limited to the secular, family domain. Patients in institutional care were also buried with healing charms and amulets, with a noteworthy assemblage from the Augustinian hospital-priory of St Mary Spital including a possible textual amulet, a ring with a protective charm, a spindle whorl, a timber rod, a Roman coin and a lead parcel containing hair. The sisters of the hospital would have prepared the corpses of the inmates for burial, ${ }^{126}$ and it is likely that their agency is detectable in the placement of these objects in the shroud.

How were these strange rites reconciled with orthodox Christian practices? The deposition of consecrated objects as grave goods, including pilgrim badges, papal bullae and inscriptions of sacred names, suggests that there was no clear distinction between magic and religious amulets placed with the dead. Later medieval manuals for priests and mendicant preachers warned against the use of any amulets; for example, John Mirk, c I403, argued that charms undermined faith and placed Christians in the devil's grip. ${ }^{127}$ And yet, some religious personnel were buried with inscriptions of sacred names, or accompanied by crosses, rosaries and croziers carved from jet, a material redolent with occult power. Not all of these objects were placed discretely within a shroud or coffin. For example, the Sandwell crosses were positioned in the grave fill behind the head of the

\footnotetext{
123 Gilchrist and Sloane 2005, 23-6.

${ }^{124}$ Kieckhefer i 994a, 379; Olsan i 992, I 36.

125 Page 2004, i6; Kieckhefer I 989.

${ }^{126}$ Rawcliffe 2003, I 9 .

127 Skemer 2006, I9I-2.
} 
deceased, rather than in a coffin, and the majority of the coppiced rods were recovered from grave fills. This placement indicates a graveside rite that was a public performance of magic, one fully integrated with the funerary rituals of the church and accepted by local clergy.

\section{THE 'HYBRIDITY’ OF MEDIEVAL MAGIC}

Archaeology has the potential to contribute a distinctive perspective to the study of medieval magic. Its deep chronology permits us to understand some later medieval rites as hybrid forms that drew on earlier beliefs. A sustained, oral tradition is indicated by the continued use of 'antique' objects, traditional amulets and natural materials with occult powers to protect the dead, and hearth ash placed in coffins was perhaps the residue of traditional rituals intended to purify the house and protect the living. Supernatural and religious spheres were brought together in addressing Christian anxieties surrounding the fate of the corpse. The incorporation of new types of amulet in burials of the 7 th to $9^{\text {th }}$ centuries may reflect a strategic selection of grave goods intended to protect the integrity of the body for the Christian resurrection. The adoption of timber rods as grave goods in the I Ith century, and textual amulets and protective charms in the I 2th century, may have emerged with the Christian interpretation of death as a harrowing journey through purgatory. Magic does not seem to have been employed routinely in medieval burial rites, but was instead directed towards the particularly vulnerable, the young or physically disabled, or during times of heightened fear of the dead. We may conclude that traces of magic in medieval burial rites represent the redirection of popular folk magic towards specific Christian purposes. Medieval people placed charms and materials with occult powers with the dead to heal or transform the corpse, to ensure its reanimation on judgement day, and to protect the dead on their perilous journey through purgatory.

\section{AGKNOWLEDGEMENTS}

This paper developed from my presidential lecture to the Society for Medieval Archaeology (2006), and I would like to take this opportunity to thank the officers and council for their support during my presidency $\left(2004^{-0}\right)$ ). The data discussed here result largely from a collaborative study with Barney Sloane on the archaeology of medieval monastic burials (2005), and I gratefully acknowledge his contribution. I am enormously grateful to Sophie Page and Howard Williams for their constructive comments on an earlier draft, and I would also like to thank Anne Lawrence, John Blair, Hella Eckardt and Eleanor Standley. For access to unpublished data and permission to use illustrations, I am grateful to Tony Gnanaratnam (University of Leicester Archaeological Services), Mark Hall (Perth Museum and Art Gallery), Richard McConnell and Liz Gardner (Context One Archaeological Services), Tim Pestell (Norwich Castle Museum), Markus Sanke (University of Bamberg), Chris Thomas and Andy Chopping (Museum of London Archaeology Service), Steve Timms (Mike Griffiths \& Associates Ltd) and Peter Yeoman (Historic Scotland). 


\section{BIBLIOGRAPHY}

\section{Published sources}

Aberdeen City Council Archaeology Unit 2007, East Kirk of St Nicholas Project 2006, Interim Report, Aberdeen.

Allason-Jones, L I996, Roman fet in the Yorkshire Museum, York: The Yorkshire Museum.

Andersson, L I989, Pilgrimsmärken och vallfart: medeltida pilgrimskultur I Skandinavien, Lund Studies in Medieval Archaeol 7.

Appadurai, A (ed) I986, The Social Life of Things. Commodities in Cultural Perspective, Cambridge: Cambridge University Press.

Archaeological Planning Consultancy, Blue Bridge Lane and Fishergate House, York. Report on Excavations Fuly 2000 to Fuly 2002, <http://www.archaeologicalplanningconsultancy.co.uk/mono/oo I/index.html> [accessed I August 2007].

Bain, S I998, 'Excavation of a medieval cemetery at Holyrood Abbey, Edinburgh', Proc Soc Antiq Scot 128, I 047-77.

Barber, B, Chew, S and White, W 2004, The Cistercian Abbey of St Mary Stratford Langthorne, Essex: Archaeological Excavations for the London Underground Limited Fubilee Line Extension Project, MoLAS Monogr I8.

Bedwin, O I975, 'The excavation of the church of St Nicholas, Angmering, I 974', Sussex Archaeol Collect I13, I6-34.

Bell, R D and Beresford, M W I987, Wharram Percy: The Church of St Martin, Soc for Medieval Archaeol Monogr II .

Bellamy, C V i 965, Pontefract Priory Excavations I 957-6I, Thoresby Soc Pub 49.

Biddle M (ed) i990, Object and Economy in Medieval Winchester: Artefacts from Medieval Winchester, Winchester Studies 7.2.

Bird, N du Q i996, 'Medieval episcopal rings from Somerset and Dorset', Somerset and Dorset Notes and Queries 34, 3-9.

Blair, J 2005, The Church in Anglo-Saxon Society, Oxford: Oxford University Press.

Blake, H, Egan, G, Hurst, J and New, E 2003, 'From popular devotion to resistance and revival in England: the cult of the holy name of Jesus and the Reformation', in Gaimster and Gilchrist 2003, I $75^{-203}$.
Blick S (ed) 2007, Beyond Pilgrim Souvenirs and Secular Badges. Essays in Honour of Brian Spencer, Oxford: Oxbow.

Bligh Bond, F I9 13, 'Glastonbury Abbey. Sixth report on the discoveries made during the excavations', Proc Somerset Archaeol Natur Hist Soc 59, 56-73.

Boddington, A I996, Raunds Furnells: The Anglo-Saxon Church and Churchyard, English Heritage Archaeol Rep 7.

Boon, G C r 1994, 'The coins', in Quinnell and Blockley I 994, I 64-5.

Brather, S, Bückler, C and Hoeper, M (eds) I 999, Archäologie als Sozialgeschichte. Studien zu Siedlung, Wirtschaft und Gesellschaft im frühgeschichtlichen Mitteleuropa. Festschrift fü Heiko Steuer zum 6o Geburtstag, Internationale Archäologie Studia Honoraria 9.

Bühler, C F r 964, 'Prayers and charms in certain Middle English scrolls', Speculum 39, $270-8$.

Bynum, C W r 995, The Resurrection of the Body in Western Christianity, 200-I336, New York: Columbia University Press.

Caciola, N r 996, 'Wraiths, revenants and ritual in medieval culture', Past Present I52, 3-45.

Cardwell, P i 995, 'The Hospital of St Giles by Brompton Bridge, North Yorkshire', Archaeol ff 152, I og-245.

Carver M O H (ed) i 993, In Search of Cult. Archaeological Investigations in Honour of Philip Rahtz, Woodbridge: Boydell.

Carver M O H (ed) 2003, The Cross goes North: Processes of Conversion in Northern Europe, Woodbridge: Boydell.

Collard, M, Lawson, JA and Homes, N 2006, Archaeological Excavations in St Giles' Cathedral Edinburgh, I98 I-93, Edinburgh: Scottish Archaeological Report 22.

Cramp, $\mathrm{R}$ 2005, Wearmouth and farrow Monastic Sites. Volume I, London: English Heritage.

Crawford, S 2004, 'Votive deposition: religion and the Anglo-Saxon furnished burial', World Archaeol 36.1, 87-Io2.

Croxford, B, Eckardt, H, Neadet, J and Weekes, J (eds) 2003, TRAC 2003. Proceedings of the I $3_{\text {th }}$ Annual Theoretical Roman Archaeology Conference, Leicester 2003, Oxford: Oxbow Books.

Cunningham, G i999, Religion and Magic. Theories and Approaches, Edinburgh: Edinburgh: University Press. 
Dabrowska, E 2005, 'Passeport pour l'au-delà. Essai sur la mentalité médiévale', Le Moyen Age 2005.2, 3 I 3-37.

Dabrowska, E et Comte, F i 993 , 'Un rite funéraire peu connu: le dépôt de bulles pontificales dans les tombes ecclésiastiques (XIV-XV siècle)', Bulletin de la Société nationale des Antiquaires de France, 209-23.

Dalton, O M, Mitchell, H P, and Couchman, J E I925, 'The Warden Abbey and Chichester croziers', Archaeologia 75, 2 I I-I5.

Daniell, C 1997, Death and Burial in Medieval England, I066-I550, London: Routledge.

Dawes, J D and Magilton, J R i98o, The Cemetery of St Helen-on-the-Walls, Aldwark, The Archaeology of York I2/I.

Detsicas, A I981, Collectanea Historica: Essays in Memory of Stuart Rigold, Kent Archaeol Soc.

Dickinson, T M i993, 'An Anglo-Saxon "cunning woman" from Bidford-onAvon', in Carver i 993, 45-54.

Dickinson, T M and Griffiths, D (eds) I 999, The Making of Kingdoms, Oxford: Anglo-Saxon Studies in Archaeology and History $\mathbf{~ o . ~}$

Duffy, E r 1992, The Stripping of the Altars. Traditional Religion in England $1400-1580$, Yale: Yale University Press.

Eckardt, H 2003, 'Remembering and forgetting in the Roman provinces', in Croxford et al 2003, 36-50.

Eckardt, $\mathrm{H}$ and Williams, $\mathrm{H}$ 2003, 'Objects without a past? The use of Roman objects in early Anglo-Saxon graves', in Williams 2003, I4 I-70.

Evans, J i 922, Magic Fewels of the Middle Ages and Renaissance, Oxford: Oxford University Press.

Evans, J and Serjeantson, M S r 933, English Medieval Lapidaries, Early English Text Society $\mathbf{1 9 0 .}$

Fanger, C I998, 'Medieval ritual magic: what it is and why we need to know more about it', in Fanger I 998, vii-xvii.

Fanger, C (ed) i 998, Conjuring Spirits: Texts and Traditions of Medieval Ritual Magic, Stroud: Sutton.

Fasham, P and Keevil, G with Coe, D I995, Brighton Hill South (Hatch Warren): An Iron Age Farmstead and Deserted Medieval Village in Hampshire, Wessex Archaeol Rep 7.
Finucane, R C I977, Miracles and Pilgrims: Popular Beliefs in Medieval England, London: Dent.

Flint, V I J r 99 I, The Rise of Magic in Early Medieval Europe, Princeton: Princeton University Press.

Fowler, C 2004, The Archaeology of Personhood. An Anthropological Approach, London: Routledge.

Frazer, J G I 890, The Golden Bough, London: Macmillan.

Gaimster, D, and Gilchrist, R (eds) 2003, The Archaeology of Reformation, Soc PostMedieval Archaeol Monogr I.

Gazin-Schwartz, A 200 I, 'Archaeology and folklore of material culture, ritual and everyday life', Int 7 Hist Archaeol 5:4, 263-80.

Geake, H I997, The Use of Grave-goods in Conversion-period England, c. 600-850, British Archaeol Rep Ser 26r.

Geake, H i999, 'Invisible kingdoms: the use of grave-goods in seventh century England', in Dickinson and Griffiths I 999, 203-I 5 .

Geake, $\mathrm{H}$ 2003, 'The control of burial practice in Anglo-Saxon England', in Carver 2003, 259-69.

Geary, P I994, Living with the Dead in the Middle Ages, Ithaca: Cornell University Press.

Gerrard, G 2003, Medieval Archaeology. Understanding Traditions and Contemporary Approaches, London: Routledge.

Gilchrist, R and Sloane, B 2005, Requiem: The Medieval Monastic Cemetery in Britain, London: Museum of London Archaeology Service.

Gnanaratnam, T 2006a, 'An urban medieval population from St Peter's, Leicester', The Archaeologist 6o, 26-7.

Gnanaratnam, T 2006b, 'Revealing a lost community', Brit Archaeol 9I, 20-2 I.

Gosden, C 2004, 'The past and foreign countries: colonial and post-colonial archaeology and anthropology', in Meskell and Preucel, i6 $\mathrm{I}-78$.

Grendon, F I9o9, 'The Anglo-Saxon charms', 7 American Folklore 22, I $05^{-237 .}$

Grieve, M i93 I, A Modern Herbal, London: Harcourt, Brace and Co.

Grimes, W F i 968, Excavation of Roman and Medieval London, London: Routledge.

Haasis-Berner, A r 999, 'Die Pilgerzeichen des I I-I4 Jahrhunderts mit einem 
Überblick über die Europäische Pilgerzeichenforschung', in Brather et al I999, $27 \mathrm{I}-7$.

Hadley, D and Buckberry, J 2005, 'Caring for the dead in late Anglo-Saxon England', in Tinti 2005, I 2 I-47.

Havergal, F E T i869, Fasti Herefordenses, Edinburgh: R Clark.

Heighway, $\mathrm{C}$ and Bryant, R I999, The Golden Minster: The Anglo-Saxon Minster and Later Medieval Priory of St Oswald at Gloucester, Counc Brit Archaeol Res Rep 117.

Heslop, D H i995, 'Excavations within the church at the Augustinian priory of Guisborough, Cleveland', Yorkshire Archaeol 7 67, 5I-I 25.

Hill, P I997, Whithorn and St Ninian: The Excavation of a Monastic Town I984-9I, Stroud: Sutton.

Hinton, D г990, 'The pendants', in Biddle I 990, 643-6.

Hinton, D 2005, Gold, Gilt, Pots and Pins. Possessions and People in Medieval Britain, Oxford: Oxford University Press.

Hodder, M I99I, Excavations at Sandwell Priory and Hall, South Staffs Archaeol and Hist Soc Trans 3i.

Ingold, T 2007, 'Materials against materiality', Archaeological Dialogues I4.I, I-I6.

Jackson, R 2006, Excavations at St James' Priory, Bristol, Oxford: Oxbow Books.

Jolly, K I985, 'Anglo-Saxon charms in the context of a Christian world view', 7 Medieval Hist I I, 279-93.

Jolly, K 2002, 'Medieval magic: definitions, beliefs, practices', in Jolly et al 2002, I$7 \mathrm{I}$.

Jolly, K, Raudvere, C and Peters, E 2002, Witchcraft and Magic in Europe. The Middle Ages, London: Athlone.

Jones, P and Olsan, L T 200o, 'The Middleham jewel: ritual, power, devotion', Viator 3i , 249-9o.

Kieckhefer, R I989, Magic in the Middle Ages, Cambridge: Cambridge University Press.

Kieckhefer, R i994a, 'The holy and the unholy: sainthood, witchcraft, and magic in late medieval Europe', 7 Medieval Renaissance Stud 24, 355-85.

Kieckhefer, R i 994b, 'The specific rationality of medieval magic', American Historical Review 99, 8 I 3-36.
Kieckhefer, R i 997, Forbidden Rites: A Necromancer's Manual of the Fifteenth Century, Stroud: Sutton.

Klemperer, W D, and Boothroyd, N 2004, Excavations at Hulton Abbey, Staffordshire, 1987-1994, Soc Medieval Archaeol Monogr $2 \mathbf{r}$.

Kopytoff, I I 986 'The cultural biography of things: commodification as process', in Appadurai I 986, 64-9I.

Lebour, N I9I4, 'White quartz pebbles and their archaeological significance', Trans Dumfriesshire Galloway Natur Hist Antiq Soc 2, I 2 I-34.

Leone, M P and Fry, G M i 999, 'Conjuring in the big house kitchen: an interpretation of African American belief systems based on the uses of archaeology and folklore sources', 7 American Folklore I12, $472-503$.

Lilley, I 2004, 'Diaspora and identity in archaeology: moving beyond the Black Atlantic', in Meskell and Preucel 2004, 287-3 I 2 .

Lindahl, C, McNamara, J and Lindow, J eds 2000, Medieval Folklore. An Encyclopedia of Myths, Legends, Tales, Beliefs, and Customs. Vol I, Santa Barbara: ABC-CLIO.

Lubin, H I990, The Worcester Pilgrim, Worcester: Worcester Cathedral Publications $\mathbf{I}$.

Lyne, M I997, Lewes Priory: Excavations by Richard Lewis 1969-82, Lewes: Lewes Priory Trust.

Mabey, R i996, Flora Britannica, London: Sinclair-Stevenson.

MacLeod, M and Mees, B 2006, Runic Amulets and Magic Objects, Woodbridge: Boydell.

Maguire, H I997, 'Magic and money in the early middle ages', Speculum 72, I03754 .

Marks, $\mathrm{R}$ 2004, Image and Devotion in Late Medieval England, Stroud: Sutton.

Marshall, Y and Gosden C (eds) I999, 'The cultural biography of objects', World Archaeol 3i.2.

Mauss, M rgo2, A General Theory of Magic, London: Routledge.

Mays, S, Harding, C and Heighway, C 2007, Wharram. A Study of Settlement on the Torkshire Wolds, XI. The Churchyard, York: York University Archaeological Publications $\mathbf{1 3}$. 
McNeill, J T and Gamer, H M I965, Medieval Handbooks of Penance, New York: Columbia University Press.

Meaney, A L ig8ı, Anglo-Saxon Amulets and Curing Stones, British Archaeol Rep 96.

Meaney, A L ig89, 'Women, witchcraft and magic in Anglo-Saxon England', in Scragg I 989, 9-40.

Merrifield, R ig87, The Archaeology of Ritual and Magic, London: Batsford.

Meskell, L and Preucel, R (eds) 2004, A Companion to Social Archaeology, Oxford: Blackwell.

Miller, P and Saxby, D 2007, The Augustinian Priory of St Mary Merton, Surrey, Excavations 1976-9o, London: MoLAS Monograph 34 .

Murray Jones, P 2007, 'Amulets: prescriptions and surviving objects from late medieval England', in Blick 2007, 92I 07.

Mynard, D C and Ivens, R J 2002, 'The excavation of Gorefields: a medieval nunnery and grange at Stoke Golding, Bucks', Rec Buckinghamshire 42, I 9-I I I.

Nailer, A 2003, 'The accessioned finds SPT82', in Aitken et al, nd 37 I-5.

Nenk, B, Margeson S, Hurley M i995, Medieval Britain and Ireland I 994, Medieval Archaeol 39, i 80-293.

Oakley, K i 965 , 'Folklore of fossils', Antiquity 39. I54, I I 7-25.

Ó Donnchadha, B 2007, 'The oldest church in Ireland's "oldest" town', Archaeol Ir 2I.I, 8-I 0 .

Olsan, L T I 992, 'Latin charms of medieval England: verbal healing in a Christian oral tradition', Oral Tradition 7, i I6-42.

Olsan, L T 2003, 'Charms and prayers in medieval medical theory and practice', Social Hist Medicine I6.3, 343-66.

O'Sullivan, J i 994, 'Excavations of an early church and women's cemetery at $\mathrm{St}$ Ronan's medieval parish church, Iona', Proc Soc Antiq Scot 124, 327-65.

Page, S 2004, Magic in Medieval Manuscripts, London: The British Museum.

Paine, S 2004, Amulets. The World of Secret Powers, Charms and Magic, London: Thames and Hudson.

Pestell, $\mathrm{T}$ in prep, 'On the occurrence and use of medieval papal bullae'.

Pluskowski, A and Patrick, P 2003, "How do you pray to God?" Fragmentation and variety in early medieval Christianity', in Carver 2003, 29-57.

Price, $\mathrm{N}$ 2002, The Viking Way. Religion and War in Late Iron Age Scandinavia, Uppsala: Aun 3I.

Quinnell, H and Blockley, K r 994, Excavations at Rhuddlan, Clwyd 1969-73, Counc Brit Archaeol Res Rep 95.

Rahtz, P i969, 'Upton, Gloucestershire, i 964-ig68', Trans Bristol Gloucestershire Archaeol Soc 88, 74-I 26.

Rawcliffe, C 2003, "The seventh comfortable work: charity and mortality in the medieval hospital', Medicina \& Storia $\mathbf{3 . 6}$, I I-35.

Rodwell, W 2006, 'Lichfield cathedral: archaeology of the nave sanctuary', Church Archaeol 7-9, I-6.

Rogerson, A, Ashley, S J, Williams, P, and Harris, A I987, Three Norman Churches in Norfolk, E Anglian Archaeol Rep 32.

Scragg, D G (ed) i989, Superstition and Popular Medicine in Anglo-Saxon England, Manchester: Manchester University Press.

Sherlock, D A and Woods, H ig88, St Augustine's Abbey: Report on Excavations I 960-78, Kent Archaeol Soc Monogr 4.

Simpson, J 2000, 'Evil Eye', in Lindahl et al 2000, 9-I3, 285-7.

Skemer, D G 2006, Binding Words. Textual Amulets in the Middle Ages, Pennsylvania: University of Pennsylvania Press.

Stead, P M r 999, 'Archaeological investigations at Tavistock Abbey i 997-I999', Proc Devon Archaeol Soc 57, I 49-203.

Stratford, N, Tudor-Craig, P and Muthesius, A I 982, 'Archbishop Hubert Walter's tomb and its furnishings', Medieval Art and Architecture at Canterbury before I 220: British Archaeological Association Conference Transactions $V, 7 \mathrm{I}-93$.

Thompson, V 2004, Dying and Death in Later Anglo-Saxon England, Woodbridge: Boydell.

Thorn, J C ig8I, 'The burial of John Dygon, abbot of St Augustine's, Canterbury', in Detsicas I98 I, 74-84.

Tinti, F (ed) 2005, Pastoral Care in Late AngloSaxon England, Woodbridge: Boydell.

Way, A I857, 'Notices of an enamelled chalice and of other ancient reliques, found on the site of Rusper Priory', Sussex Archaeol Collect 9, 303-I I. 
White, R i 988, Roman and Celtic Objects from Anglo-Saxon Graves, Brit Archaeol Rep I9I.

Wilkie, L A r997, 'Secret and sacred: contextualizing the artifacts of AfricanAmerican magic and religion', Historical Archaeol 3i.4, 8 I- 06.

Williams, H (ed) 2003, Archaeologies of Remembrance. Death and Memory in Past Societies, New York: Kluwer/Plenum.

Williams, H 2007, 'The emotive force of early medieval mortuary practices', Archaeol Rev Cambridge 22.I, I 07-23.

Wilson, S 2000, The Magical Universe: Everyday Ritual and Magic in Pre-Modern Europe, London: Hambledon.

Woodfield, C 2005, The Church of Our Lady of Mount Carmel and some Conventual Buildings at the Whitefriars, Coventry, Brit Archaeol Rep 389.
Wyckoff D I967, Albertus Magnus Book of Minerals, Oxford: Clarendon.

Yeoman, $\mathrm{P}$ and James $\mathrm{H}$ in prep, Excavations at St Ethernan's Priory, Isle of May, Fife, I $992-7$.

Zeiten, M Koktvedgaard i997, 'Amulets and amulet use in Viking Age Denmark', Acta Archaeologica 68, I-74.

\section{Unpublished sources}

Aitken, R, Bowsher, D, Daykin, A, Harward, C, Holder, N, McKenzie, M, Pitt, $\mathrm{K}$ and Thomas, $\mathrm{C}$ nd, 280 Bishopsgate and the Spitalfields Ramp: a postexcavation assessment (MoLAS unpub report), $37 \mathrm{I}-5$.

Wooldridge, K ig88, Excavations at St Bartholomew-the-Great church, Clothfair, London EGi, unpub Museum of London Level III archive report.

\section{FRENCH, GERMAN AND ITALIAN ABSTRACTS}

Résumé

\section{De la magie pour les morts? L'archéologie de la magie dans les sépultures du milieu et de la fin du Moyen Âge par Roberta Gilchrist}

Cet article examine les configurations du positionnement d'objets et de matériaux apotropaiques dans des sépultures datant du milieu et de la fin du Moyen Âge (du XI ${ }^{\mathrm{e}}$ au XV $\mathrm{XV}^{\mathrm{e}}$ siècle) découvertes en Grande-Bretagne. Une classification interdisciplinaire est mise au point pour identifier: (I) les breloques de guérisseur et les amulettes de protection; (2) les objets perçus comme ayant un pouvoir naturel occulte; (3) les articles 'antiques' traités comme s'ils avaient un pouvoir occulte; enfin, (4) les pratiques rares ayant pu être associées à la magie démoniaque de la divination ou de la sorcellerie. En faisant des comparaisons avec les amulettes déposées dans des tombes remontant à la période de la conversion au christianisme (du VII ${ }^{\mathrm{e}}$ au XIX ${ }^{\mathrm{e}}$ siècle), nous démontrons que le placement d'amulettes auprès des morts jouait un rôle stratégique dans les croyances chrétiennes et visait à transformer ou à protéger le cadavre. Nous concluons que les traces matérielles de magie observées dans les tombes de la fin de la période médiévale sont liées à la magie populaire pratiquée par les femmes dans le cadre des soins qu'elles prodiguaient à leur famille et s'appuie sur des traditions antérieures. Ces pratiques populaires, intégrées aux préoccupations chrétiennes et tolérées par le clergé local, étaient peut-être destinées à guérir ou à reconstituer le cadavre, à lui rendre la vie le jour du jugement dernier et à protéger le défunt vulnérable pendant la traversée du purgatoire.

\section{Zusammenfassung}

\section{Magie für die Toten? Die Archäologie der Magie in spätmittelalterlichen Begräbnisstätten von Roberta Gilchrist}

Diese Arbeit untersucht Verhaltensmuster in der Verwendung von apotropäischen Objekten und Materialien in hoch- bis spätmittelalterlichen Begräbnisstätten in Großbritannien ( I I . bis I 5. Jahrhundert). Sie entwickelt eine interdisziplinäre Klassifizierung zur Identifizierung: 
( I) heilende Talismane und schützende Amulette; (2) Objekte, denen eine okkulte natürliche Kraft zugeschrieben wurde; (3) 'alte' Gegenstände, die über eine okkulte Kraft verfügen sollten; und (4) seltene Praktiken, die mit der Dämonenmagie von Weissagungen oder Hexerei in Verbindung gebracht wurden. Aufgrund von Vergleichen mit Amuletten aus Gräbern aus der Zeit der Konvertierung zum Christentum im 7. bis 9. Jahrhundert wird behauptet, dass der Gebrauch von Amuletten bei Toten für den christlichen Glauben strategisch war und dazu diente, die Leiche zu transformieren oder zu beschützen. Der Rückschluss ist, dass materielle Spuren von Magie in spätmittelalterlichen Gräbern eine Verbindung zur Volksmagie haben, die von Frauen zur Beschützung ihrer Familien ausgeübt wurde und auf dem Wissen früherer Bräuche aufbaute. Diese volkstümliche Magie wurde in christliche Glaubensformen integriert und von den örtlichen Geistlichen toleriert. Sie diente vielleicht dazu, den Toten zu heilen oder wiederherzustellen, um seine Neubelebung am Jüngsten Tag zu garantieren und den verletzbaren Toten auf dem Weg durch das Fegefeuer zu beschützen.

\section{Riassunto}

\section{Magia per i morti? Archeologia del magico nelle tarde sepolture medievali $d i$} Roberta Gilchrist

Questa relazione esamina gli schemi nel collocamento di oggetti e materiali apotropaici nelle sepolture dell'alto fino al tardo medioevo in Gran Bretagna (dall'XI al XV secolo), sviluppando una classificazione interdisciplinare al fine di identificare: (I) talismani curativi e amuleti protettivi; (2) oggetti a cui veniva attribuita una naturale potenza occulta; (3) oggetti 'antichi' trattati come se possedessero potenza occulta; (4) pratiche rare che potrebbero essere state associate con la magia demonica della profezia o stregoneria. Il raffronto con alcuni amuleti depositati nelle tombe del periodo della conversione compreso tra il VII e il IX secolo porta alla convinzione che la collocazione degli amuleti accanto ai morti fosse strategica per le credenze cristiane, con il fine di trasformare o proteggere il cadavere. La conclusione è che le tracce materiali di magia nei tardi sepolcri medievali si ricollegano alla magia popolare, che veniva eseguita dalle donne all'interno del focolare domestico e attingeva alla conoscenza di tradizioni precedenti. Questa magia popolare veniva coordinata con le questioni cristiane ed era tollerata dal clero locale, forse al fine di risanare o ricostituire il cadavere, per garantirne la rianimazione il giorno del giudizio, e proteggere i vulnerabili morti nel loro viaggio attraverso il purgatorio. 